UNITED STATES ARMY CORPS OF ENGINEERS

\title{
project pre-sGHOONER
}

Nevada Test Site-February,1964

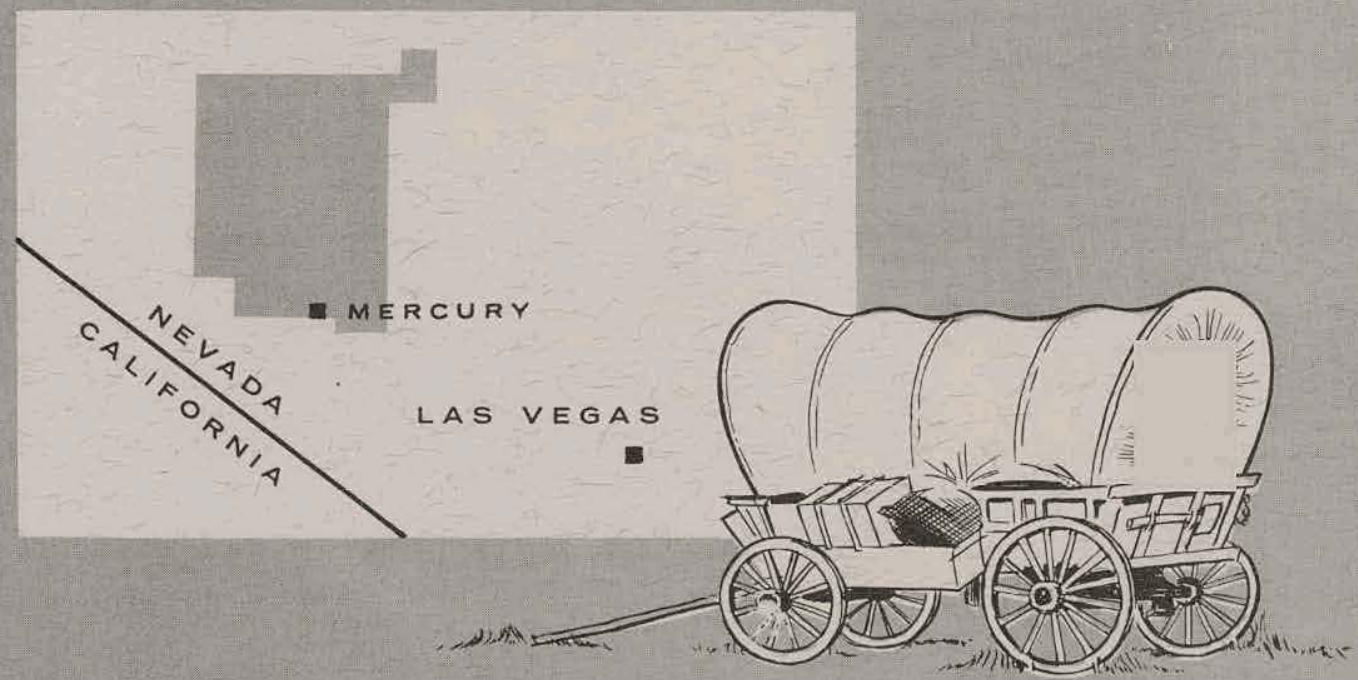

\section{Stem Design and Shotcrete, Grout, and Concrete Support}

KENNETH L. SAUCIER, Project Officer

U. S. Army Engineer Waterways Experiment Station

Vicksburg, Mississippi 


\section{DISCLAIMER}

This report was prepared as an account of work sponsored by an agency of the United States Government. Neither the United States Government nor any agency Thereof, nor any of their employees, makes any warranty, express or implied, or assumes any legal liability or responsibility for the accuracy, completeness, or usefulness of any information, apparatus, product, or process disclosed, or represents that its use would not infringe privately owned rights. Reference herein to any specific commercial product, process, or service by trade name, trademark, manufacturer, or otherwise does not necessarily constitute or imply its endorsement, recommendation, or favoring by the United States Government or any agency thereof. The views and opinions of authors expressed herein do not necessarily state or reflect those of the United States Government or any agency thereof. 


\section{DISCLAIMER}

Portions of this document may be illegible in electronic image products. Images are produced from the best available original document. 
This document is a report of nuclear explosives studies for civil construction, conducted under the Civil Works General Investigations of the U. S. Army Corps of Engineers. The work is part of a nuclear excavation research program being carried out jointly with the Atomic Energy Commission. The results and findings of this report are those of the author(s) and not necessarily those of the AEC or Corps of Engineers. Accordingly, reference to this materials must credit the author(s). This report is the property of the Department of the Army and, as such, may be reclassified or withdrawn from circulation as appropriate by the Corps of Engineers.

Printed in USA. Price $\$ .50$ Available from the office of Technical Services, Department of Commerce, Washington 25, D. C. 
PROJECT PRE-SCHOONER

PNE $501 \mathrm{~F}$

STEM DESIGN AND SHOTCRETE, GROUT, AND CONCRETE SUPPORT

Kenneth L. Saucier, Project Officer

U. S. Army Engineer Waterways Experiment Station

Corps of Engineers

Vicksburg, Mississippi

November 1964 


\section{THIS PAGE \\ WAS INTENTIONALLY \\ LEFT BLANK}


FOREWORD

This report supersedes: PNE 501, Preliminary Report, Project Pre-SCHOONER, Stem Design, dated August 1964. The study described herein was authorized by Intra-Army order for Reimbursable Work or Service, No. NCGIAO 1-63, Change No. 1, dated 19 August 1963, from the U. S. Army Engineer Nuclear Cratering Group, Livermore, California, to the U. S. Army Engineer Waterways Experiment Station (WES).

The work was performed at the WES Concrete Division and at the U. S. Atomic Energy Commission's Nevada Test Site under the supervision of Mr. Thomas B. Kennedy, Chief, WES Concrete Division, and Messrs. James M. Polatty, William O. Tynes, and Kenneth L. Saucier, Project Officer. Pfc. John C. Wines was project leader for the stem design study and Mr. George V. Marler was project leader for the shotcrete, grout, and concrete support. This report was prepared by Messrs. Saucier, Wines, and Marler.

Director of the WES during the conduct of this investigation and preparation of this report was Colonel Alex G. Sutton, Jr., CE. Technical Director was Mr. J. B. Tiffany. 
THIS PAGE

\section{WAS INTENTIONALLY \\ LEFT BLANK}


CHAPTER I INTRODUCTION . . . . . . . . . . . . . . . . . . . . . . . I I

1.1 Purpose and Scope of Project . . . . . . . . . . . . . I I

1.2 Scope of WES Participation in Project . . . . . . . . . . I 1

1.3 Scope of This Report . . . . . . . . . . . . . . . 3

CHAPTER 2 IABORATORY INVESTIGATION . . . . . . . . . . . . . . . 5

2.1 Objectives . . . . . . . . . . . . . . . . . 5

2.2 Shotcrete Mixture . . . . . . . . . . . . . 5

2.3 Grout Mixture ...................... 5

2.4 Concrete Mixture . . . . . . . . . . . . . . . 6

2.4.1 Assumptions .................. 6

2.4.2 Design Criteria . . . . . . . . . . . . . 6

2.4.3 Mixture Data . . . . . . . . . . . . 8

2.4.4 Tests.................... . . . 9 9

2.4 .5 Results.................... . . 10

2.4.6 Design Approach .. . . . . . . . . . . . . . 11

2.4.7 Recommendations................ . . 12

LHAPTER 3 FIELD WORK . . . . . . . . ............. . . . . 13

3.1 Shotcrete Placement . . . . . . . . . . . . . 13

3.1.1 Equipment .. . . . . . . . .......... 13

3.1.2 Procedure .................... 13

3.2 Grouting . . . . . . . . . . . . . . . . 14

3.2.1 Equipment . . . . . . . . . . . . . . 14

3.2.2 Procedure .................... . . . . . . . 14

3.3 Concrete Placement ............... . . . . 14

3.3.1 Equipment.................. . . . . 14

3.3.2 Procedure .................... 17

CHAPTER 4 TEST RESULTS, DISCUSSION, AND CONCLUSIONS • • . • . . . . 19

4.1 Shotcrete................... . . . . 19

4.2 Grout . . . . . . . . . . . . . . . . 19

4.3 Concrete .. . . . . . . . . . . . . . . 19

4.4 Stems . . . . . . . . . . . . . . . 20

4.4.1 Site Alfa................... . . . . 20

4.4.2 Site Bravo . . . . . . . . . . . . . . 22

4.4.3 Site Charlie . . . . . . . . . . . . . 22 
4.4.4 Site Delta . . . . . . . . . . . . . . . . 22

4.4.5 Summary .................. . . . . 22

TABLES $1-4$

APPENDIX A: SPECIAL EQUIPMENT

APPENDIX B: MOHR'S CIRCLE ANALYSIS

APPENDIX C: EFFICIENCY OF SHEAR KEYS

ÁPPENDIX D: ḊESIGN CALCULATIONS 


\section{(changes were ditorated}

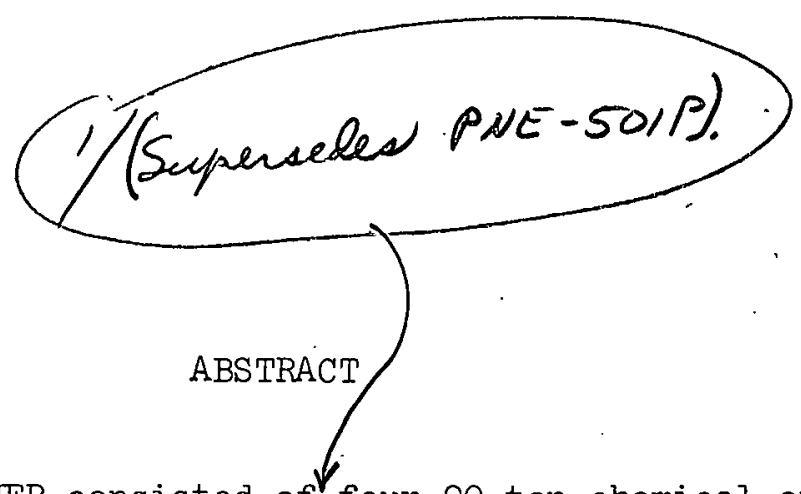

Lroject Pre-SCHOONR-eonststed-of four 20-ton chemical-explosive detons in hard, dry rock at scaled depths of burs.t. of 135, 160, ${ }^{\prime} 185$, and $210 \mathrm{ft} / \mathrm{kt} 1 / 3.4$. The primary purpose of the project was to increase the knowledge of crater dimensions in hard, dry rock as a function of depth of burst and type of explosive./2 This fallowing_work-performed for the project by-persongel-of-the-U.S.-Army-

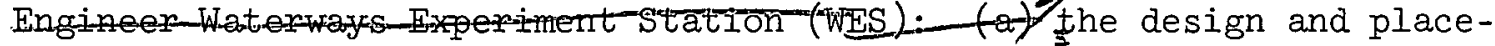
ment of grout mixtures used in grouting satellite holes surrounding each ground zero location, (the design and supervision of the placement of a shotcrete mixture used in lining the walls of each of the shot cavities, and (et) the design and supervision of the placement of a concrete mixture used in stemming the access holes to each of the shot cavities, are descinbed. 
STEM DESIGN AND SHOTCRETE, GROUT, AND CONCRETE SUPPORT

\author{
CHAPTER 1 \\ INTRODUCTION
}

\title{
1.1 PURPOSE AND SCOPE OF PROJECT
}

Project Pre-SCHOONER, a field cratering experiment conducted using chemical explosives, was sponsored by the U. S. Army Engineer Nuclear Cratering Group (NCG), Lawrence Radiation Laboratory (LRL), Livermore, California. The' NCG Technical Director's Operation Plan stated that the purpose of the project was "to improve our knowledge of crater dimensions in hard, dry rock as a function of depth of burst and type of explosive. The data will be used in the design of the SCHOONER 100-kt nuclear cratering experiment in hard, dry rock and in the general development of a theory of cratering and techniques for predicting slope stability and other engineering próperties of nuclear craters."

Four 20-ton chemical explosives were emplaced and detonated in 10-ft-diameter spheres at scaled depths of burst of 135, 160, 185, and $210 \mathrm{ft} / \mathrm{kt}^{1 / 3.4}$ in the massive bedded basalt formation of Buckboard Mesa, Area 18, at the U. S. Atomic Energy Commission's Nevada Test Site (NTS). With existing data, it is difficult to confidently predict the variation in crater dimensions as the scaled depth of burst in hard, dry rock is varied in the range 135 to $210 \mathrm{ft} / \mathrm{kt}^{1 / 3.4}$. It is also difficult to determine whether the apparent agreement between nuclear and chemical explosive data is fortuitous. It was hoped that data obtained in Project Pre-SCHOONER would clarify these uncertainties and add to the general knowledge of cratering phenomena and behavior.

\subsection{SCOPE OF WES PARTICIPATION IN PROJECT}

The Soils Division of the U. S. Army Engineer Waterways Experiment Station (WES) determined the geologic conditions of several possible PreSCHOONER sites at NTS, and four sites were selected. The code names for the four shots, the shot hole numerical designations, and the locations (in NTS coordinates) and geologic conditions of the four test sites were as follows: 


\begin{tabular}{|c|c|c|c|c|}
\hline & Alfa & Bravo & Charlie & Delta \\
\hline $\begin{array}{l}\text { NCG exploratory } \\
\text { hole No. }\end{array}$ & 7.0 & 4.0 & 3.0 & 11.0 \\
\hline $\begin{array}{l}\text { Fenix and Scisson } \\
\text { hole No. }\end{array}$ & $\mathrm{Ul} 8 \mathrm{f}$ & $\mathrm{U} \perp \mathrm{cc}$ & $\mathrm{u} 18 \mathrm{e}$ & U $8 \mathrm{~b}$ \\
\hline NTS coordinates & $\begin{array}{l}\text { N } 855,128.76 \\
\text { E } 589,719.22\end{array}$ & $\begin{array}{l}\text { N } 851,996.96 \\
\text { E } 595,560.92\end{array}$ & $\begin{array}{l}\text { N } 854,131.75 \\
\text { E } 594,587.88\end{array}$ & $\begin{array}{l}\text { N } 858,091.53 \\
\text { E } 592,410.46\end{array}$ \\
\hline $\begin{array}{l}\text { Depth of overburden } \\
\text { to vesicular ba- } \\
\text { salt, ft }\end{array}$ & 4 & 3 & 5 & 3 \\
\hline $\begin{array}{l}\text { Depth to laminated } \\
\text { basalt, ft }\end{array}$ & 18 & 20 & 29 & 29 \\
\hline $\begin{array}{l}\text { Depth to massive } \\
\text { (solid) basalt, } \\
\text { ft }\end{array}$ & 30 & 46 & 36 & 47 \\
\hline $\begin{array}{l}\text { Depth of burst } \\
\text { (i.e. depth to } \\
\text { center of emplaced } \\
\text { sphere), ft }\end{array}$ & 39 & 51 & 67 & 43 \\
\hline
\end{tabular}

The WES Concrete Division was responsible for (a) the design of a reinforced concrete stem for the four shot holes that would react in the same manner as the in-situ basalt upon charge detonation, (b) the design and supervision of the placement of a concrete mixture to be used in stemming the access holes to each of the four shot cavities, (c) the design and supervision of the placement of a shotcrete mixture to be used in lining the walls of each of the four shot cavities, and (d) the design and placement of colored grout mixtures to be used in grouting the three satellite holes surrounding each shot hole.

The concrete stem mixture, the radial hole grout mixture, and the pneumatically applied mortar mixture (gunite, or shotcrete) were all designed in the laboratory to obtain the required strength and physical characteristics. Concrete was selected for use in the stemming because it was considered to be the strongest material readily available and economically feasible. The purpose of the shotcrete was to line the walls of the shot cavities to provide a spherical, relatively smooth surface. The small radial holes associated with each sphere were planned to facilitate 
postshot exploration of the craters. Fig. 1 shows a typical centerline section of the shot hole configuration.

In order to effectively perform the field work, a crew. of from two to six men was required at the jobsite during the two-month construction period. Test specimens of the three mixtures (1.e. shotcrete, grout, and concrete) were cast at the site, sent to the WES, and tested as a check on the quality of the fleld-mixed mixtures. A postshot inspection of the craters yielded observations on the mechanism of failure and the efficency of the stems.

\subsection{SCOPE OF THIS REPORT}

This report describes the stem design and the shotcrete, grout, and concrete support accomplished by WES in connection with Project.PreSCHOONER. The stem design work was reported in an earlier report (PNE 501, Preliminary Report, Project Pre-SCHOONER Stem Design, dated August 1964), but the data therein have been republished herein to provide'a complete description of the stem design, and shotcreting, grouting, and concrete work in one volume. 


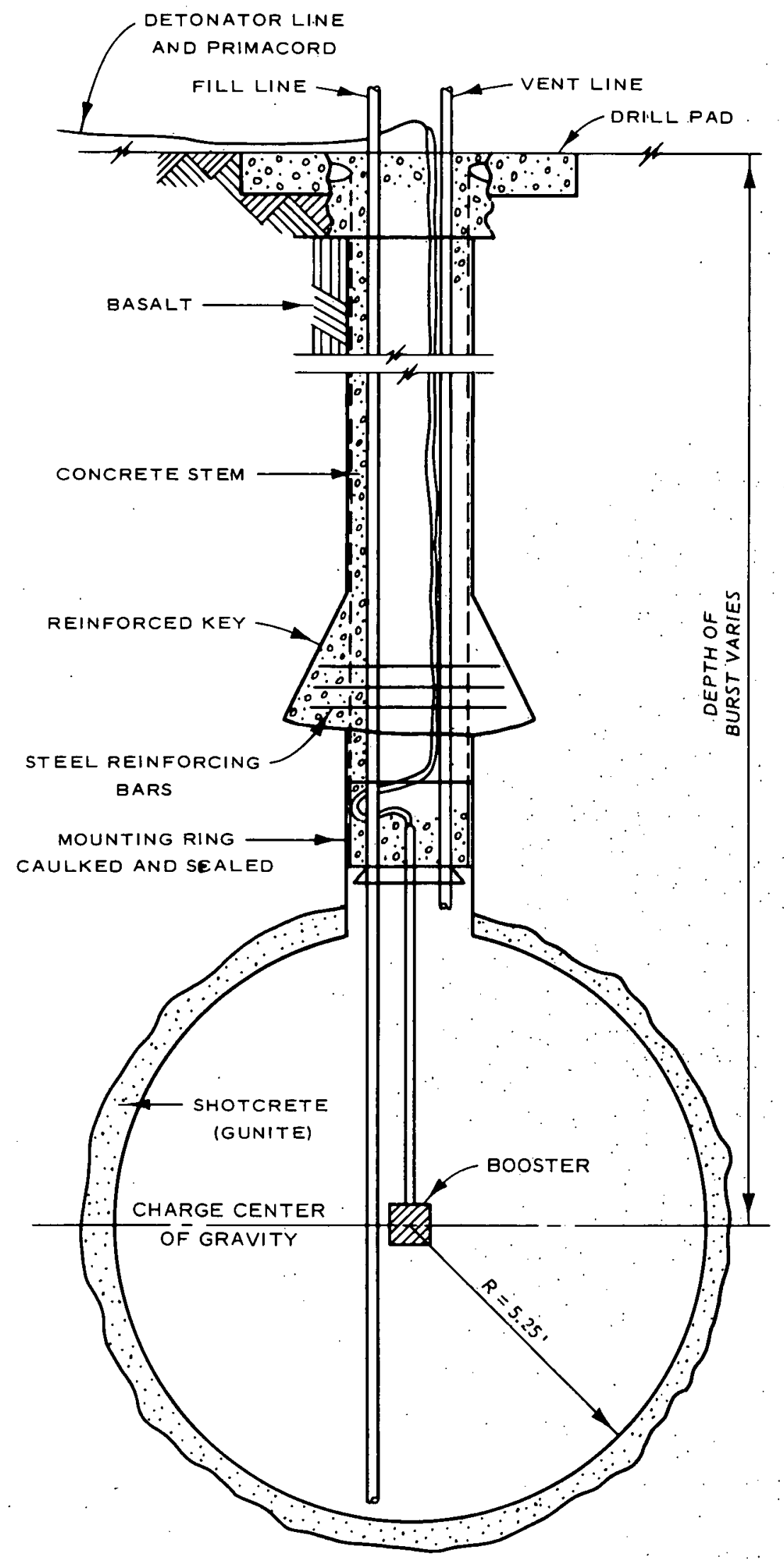

Fig. 1. Center-line section of typical charge emplacement 
CHAPTER 2

LABORATORY INVFSTIGATION

\subsection{OBJECTIVES}

The objectives of the laboratory investigation were to design (a) a shotcrete mixture for lining the walls of each shot cavity, (b) a grout mixture for grouting the satellite holes surrounding each ground zero location, and (c) a concrete stem which would replace the in-situ material in such a manner as to permit a crater to develop as if an access hole had not been drilled.

\subsection{SHOTCRETE MIXTURE}

The shotcrete mixture was designed to have a 7-day compressive strength of $6000 \mathrm{psi}$ and a slump of $3 \pm 1$ in. This design would permit. effective placement by pneumatic means. A second mixture, containing an accelerator, was developed in the field to expedite placing. The proportions for both shotcrete mixtures are given in table 1 .

\subsection{GROUT MIXTURE}

Based on the physical properties of cores previously obtained from holes in Buckboard Mesa, the following desired criteria were selected for use in the design of a grout mixture to be used in grouting the satellite holes: (a) compressive strength of $20,000 \mathrm{psi}$, (b) ultrasonic pulse velocity of 14,000 fps, and (c) density of 165 to $185 \mathrm{lb}$ per cu ft. One each of three colors--maroon, beige, and black (the natural color of the grout)--was required for grout in each satellite hole at each of the four shot sites. Use of the different colors would permit postshot identification of pieces of grout in the ejecta.

Because a compressive strength of 20,000 psi would be practically impossible to achieve, attention was focused on obtaining the desired pulse velocity and density. The desired grout mixture was developed by proportioning a series of mixtures with various types of cements, sands, and admixtures. Grout mixture design information is given in table 1 . 
2.4.1 Assumptions. In order to achieve a practical solution to the stem design problem, simplifying assumptions.were made as follows:

a. A significant portion of the blast energy will be lost if a proper stem is not emplaced.

b. The stem should be designed so that it would not react as a projectile when subjected to the forces of the detorlation, but rather would react essentially as a part of the surrounding medium. Conversely, the stem should not be so strong and monolithic in its reaction to the blast loading that it will not fail at the same time and in the same manner as the in-situ medium. Ideally the stem should have structural properties commensurate with those of the in-situ, undisturbed medium.

c. The punch-out (bond-shear) test developed for simulating the access hole is a representative test and the modeling effect is linear.

d. The concrete shear key area should be reduced by 20 percent to counteract the increase in the shear strength of the key due to the horizontal steel reinforcing bars.

e. The 5-ft space at the top of the detonation sphere in the stem should be neglected in the stem design. This space will contain equipment which will prevent complete filling by the concrete and thereby render the bond ineffective.

2.4.2 Design Criteria. The stemming material was to be a concrete mixture designed to match as closely as possible the structural properties of the in-situ basalt. The structural properties considered to be the most. important in this regard were tensile strength, shear strength, and compressive strength. Two uther properties, density and pulse velocity, were to be closely matched by the concrete, but these were secondary properties with respect to the stem design. Considering the structural properties, it was obvious that the continuous medium would react differently than laboratory specimens. The standard tests for tensile, shear, and compressive strengths are unconfined tests performed on specimens extracted from the continuous medium. In reality, the application of unconfined test values in lieu of confined test values is only an approyimation.

A further limitation on the design of a proper stem was a lack of 
Table 1

Shotcrete and Grout Materials and Mixture Proportions

\begin{tabular}{|c|c|c|c|c|c|}
\hline Item & Material & $\begin{array}{l}\text { Specific } \\
\text { Gravity } \\
\end{array}$ & $\begin{array}{l}\text { Unit Weight } \\
\text { (Solid) } \\
\text { Ib/cu ft } \\
\end{array}$ & $\begin{array}{c}\text { Solid Volume per } \\
\text { I-Bag Batch } \\
\text { cu ft } \\
\end{array}$ & $\begin{array}{l}\text { Weight per } \\
\text { 1-Bag Batch } \\
\text { Ib } \\
\end{array}$ \\
\hline Shotcrete & $\begin{array}{l}\text { Portland cement, Type III } \\
\text { NTS sand (Area 5) } \\
\text { Water } \\
\text { Gypsum base accelerator }\end{array}$ & $\begin{array}{l}3.15 \\
2.59 \\
1.00 \\
2.75\end{array}$ & $\begin{array}{r}196 \cdot 24 \\
161 \cdot 36 \\
62.30 \\
171 \cdot 32\end{array}$ & $\begin{array}{l}-- \\
-- \\
-- \\
--\end{array}$ & $\begin{array}{l}-- \\
-- \\
-- \\
--\end{array}$ \\
\hline Mixture 1 & $\begin{array}{l}\text { Portland cement, Type III } \\
\text { NTS sand (Area 5) } \\
\text { Water }\end{array}$ & $\begin{array}{l}-- \\
-- \\
--\end{array}$ & $\begin{array}{l}-- \\
-- \\
--\end{array}$ & $\begin{array}{l}0.479 \\
1.748 \\
0.815\end{array}$ & $\begin{array}{r}94.0 \\
282.0 \\
50.8\end{array}$ \\
\hline Mixture 2 & $\begin{array}{l}\text { Portland cement, Type III } \\
\text { NTS sand (Area 5) } \\
\text { Gypsum base accelerator } \\
\text { Water }\end{array}$ & $\begin{array}{l}-- \\
-- \\
-- \\
--\end{array}$ & $\begin{array}{l}-- \\
-- \\
--\end{array}$ & $\begin{array}{l}0.479 \\
1.748 \\
0.117 \\
0.905\end{array}$ & $\begin{array}{r}94.0 \\
282.0 \\
20.0 \\
56.4\end{array}$ \\
\hline Grout & $\begin{array}{l}\text { Calcium-aluminate cement } \\
\text { Magnetite sand } \\
\text { Water } \\
\text { Concrete coloring* }\end{array}$ & $\begin{array}{l}3.15 \\
4.65 \\
1.00 \\
---\end{array}$ & $\begin{array}{r}196.24 \\
289.69 \\
62.30 \\
--\end{array}$ & $\begin{array}{l}0.479 \\
0.621 \\
0.754 \\
--\end{array}$ & $\begin{array}{r}94.0 \\
180.0 \\
47.0 \\
5.0\end{array}$ \\
\hline
\end{tabular}

* Added to two of the three mixtures. 
dynamic testing facilities of sufficient capacity. The values determined in the laboratory in this study were static values, and since the relation of dynamic to static bond-shear is not known, the simple static values were used. However, these values probably were conservative since the dynamic design values that were known were usually higher than corresponding static values.

The basic criterion was to design the total bond-shear resistance of the concrete-basalt interface to be at least equal to the total unconfined static shear resistance of the basalt by using shear keys and bondshear values. The resistance capacity of the stem was considered separately in each stratum of the basalt. Shear keys were used whenever the bond-shear value between the stemming material and the particular stratum of basalt was less than the static unconfined shear strength of that stratum. These keys were designed from a dynamic approach since literature on this particular subject was available.

Another factor considered was the tensile force perpendicular to the axis of the key resulting from the compression wave of the blast. Hor $-\cdots$. izontal, radial steel was added in the key regions in sufficient quantity to match the static unconfined tensile strength of the stratum in which the key was placed. Bond of the steel to the concrete was essential in creating this tensile strength; therefore, a value close to that of the ultimate static bond strength of steel in concrete was used.

The 21-day strength of the concrete design proportioned at WES and cured under optimum conditions in the laboratory was reduced 30 percent for design calculations because of unknown field curing conditions and the uncertainty of the detonation schedule.

For ease of mining, the keys were of the "dovetail". type, designed shoulder down, with a convenient ratio of key shoulder size to key height. A sufficient spacing between keys was chosen to avoid fracture during mining.

There was ro requirement for vertical reinforcing steel in this design approach.

The key design criteria were based on DASA. Report 1339, "Dynamic Shear Strength of Concrete Keys," by the Massachusetts Institute of Technology (MIT) Department of Civil Engineering, dated January 1959. 
Pertinent criteria contained in that report and used in thịs design are:

For a single row of keys

$$
\tau / f_{c}^{\prime}=0.64
$$

where

$$
\begin{aligned}
\tau & =\text { shear resistance of a key, psi } \\
f_{c}^{\prime} & =\text { compressive strength of concrete, psi }
\end{aligned}
$$

Efficiency (see Appendix C) for multiple rows of keys is:

$$
E=17.56\left(\frac{1.125}{K-0.7}+1.95\right)
$$

where

$$
\begin{aligned}
& E=\text { efficiency, } \% \\
& K=\text { number of keys }
\end{aligned}
$$

The stemming for each access hole was designed individually based on the

\begin{tabular}{|c|c|c|c|}
\hline Material & $\begin{array}{c}\frac{\text { Batch Data B B }}{\text { Solid Volume }} \\
\text { cu ft }\end{array}$ & Based & $\begin{array}{c}\text { on } 1 \text { Bag of Cement } \\
\text { Saturated Surface } \\
\text { Dry Weight, lb }\end{array}$ \\
\hline Cement, type III portland & 0.479 & & 94.00 \\
\hline Metallic aggregate & 0.085 & & 30.00 \\
\hline NTS alluvium sárd & 0.417 & & 67.29 \\
\hline Magnetite sand & 0.417 & & 117.69 \\
\hline $\begin{array}{l}\text { NTS alluvium coarse aggregate } \\
\text { Water }\end{array}$ & $\begin{array}{l}1.421 \\
0.689\end{array}$ & & $\begin{array}{r}237.25 \\
42.92\end{array}$ \\
\hline Concrete coloring & - & & $\therefore 5.00$ \\
\hline $\begin{array}{l}\text { Water-reducing admixture } \\
\text { (lignin base) }\end{array}$ & $\therefore$ & & 0.25 \\
\hline
\end{tabular}
stratification shown graphically in Appendix D, fig. DI.

2.4.3 Mixture Data. The concrete mixture to be used in stemming was designed to have a cement factor of 7.5 bags per cu yd, a water-cement ratio of 0.48 by weight, and a slump of $3-1 / 2 \pm 1 / 2 \mathrm{in}$. The mixture proportions were:

At each quarter height of the stem, the concrete color was changed to aid in the postshot study of crater ejecta. The metallic aggregate, a commercial product consisting primarily of iron filings, was used to increase the density and prevent shrinkage of the mixture. Sieve analysis was not made on this aggregate. The coarse aggregate was nominal $1-1 / 2-i n$. maximum size NTS alluvium. The grading of each of the aggregates except the metallic was as follows: 


$\begin{array}{lcccc}\begin{array}{c}\text { Sieve } \\ \text { Size }\end{array} & \begin{array}{c}\text { Coarse } \\ \text { Aggregate }\end{array} & \begin{array}{c}\text { Magnetite } \\ \text { Fine Aggregate }\end{array} & \begin{array}{c}\text { Alluvium } \\ \text { Fine Aggregate }\end{array} \\ \text { 2-in. } & 100 & -- & -- \\ \text { l-1/2-in. } & 98 & -- & -- \\ \text { 1-in. } & 60 & -- & -- \\ \text { 3/4-in. } & 45 & -- & -- \\ \text { 1/2-in. } & 32 & -- & -- \\ \text { 3/8-in. } & 23 & -- & 100 \\ \text { No. } 4 & 2 & 100 & 92 \\ \text { No. } 8 & -- & 100 & 54 \\ \text { No. } 16 & -- & 99 & 29 \\ \text { No. } 30 & -- & 80 & 13 \\ \text { No. } 50 & -- & 30 & 3 \\ \text { No. } 100 & -- & 0 & . .\end{array}$

The specific gravities of the coarse, magnetite fine, and alluvium fine aggregates were $2.68,4.90$, and 2.59, respectively; the percentages of absorption were $0.6,0.5$, and 0.2 for the same respective aggregates.

2.4.4 Tests. Bond-shear, tensile, and compressive strength tests were conducted on the concrete for comparison with the three different types of basalt (i.e: vesicular, laminated, and solid) at the Pre-SCHOONER test site. A description of these tests follows.

\section{Punch-Out Tests}

The purpose of the punch-out tests was to simulate, on a small scale, the effect of the blast on the concrete stem. . Six-in.diameter cores obtained from the test site were sawed into lengths ranging from 3 to $12 \mathrm{in.}$ These specimens were then grouted into a square form (Appendix A, fig..Al) to furnish stability during the drilling of a 3-in.-diameter hole through the center of each specimen. The holes in the specimens were then filled to different depths with the stem concrete mixture, which was allowed to cure for 14 days. In each specimen, the top end of the concrete "plug" was capped with a high-strength gypsum compound. A typical specimen is shown in fig. A2. Each specimen was then placed in the punch-out stabilizing frame (fig. A3) and cemented in and to the frame with hydrostone to effect a condition of biaxial confinement. The frame was placed in a 440,000-1b-capacity testing machine, a 3-in.diameter steel piston ( $f i g$. A4) was placed on the capped concrete plug, and the entire assembly was carefully leveled to avoid eccentric loading. The piston was loaded (fig. A5) until the bond between the concrete and 
basalt failed. In all punch-out tests on the laminated and vesicular basalt; the basalt cracked radially, indicating that the bond failed at the same time the basalt failed.

\section{Conventional Tests}

Static and dynamic tensile splitting strength and static compressive strength tests were performed on the basalt and stemming concrete to obtain data for use in the design analysis and to compute, shear strength, as no actual shear strength determinations were made on the basalt or concrete. The shear values used in the calculations were obtained from the static compressive and tensile strength values plotted on a Mohr's circle. The shear strength analysis is presented in Appendix B.* 2.4.5 Results. The results of the various tests are given below:

\begin{tabular}{|c|c|c|c|}
\hline Tests & Material & $\begin{array}{l}\text { Number of } \\
\text { Specimens } \\
\text { Tested } \\
\end{array}$ & $\begin{array}{l}\text { Average } \\
\text { Strength } \\
\text { psi } \\
\end{array}$ \\
\hline $\begin{array}{l}\text { Punch-Out } \\
\text { (Bond-Shear) }\end{array}$ & 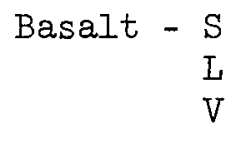 & $\begin{array}{l}6 \\
3 \\
7\end{array}$ & $\begin{array}{l}1,180 \\
2,325 \\
1,560\end{array}$ \\
\hline \multirow[t]{2}{*}{$\begin{array}{l}\text { Static Compressive } \\
\text { Strength (Unconfined) }\end{array}$} & $\begin{array}{r}\text { Basalt - S } \\
\text { I } \\
\text { V }\end{array}$ & $\begin{array}{l}3 \\
2 \\
4\end{array}$ & $\begin{array}{r}18,100 \\
13,250 \\
8,450\end{array}$ \\
\hline & Concrete & 3 & 7,360 \\
\hline \multirow[t]{2}{*}{$\begin{array}{l}\text { Static Tensile Splitting } \\
\text { Strength (Unconfined) }\end{array}$} & $\begin{array}{r}\text { Basalt - S } \\
\mathrm{L} \\
\mathrm{V}\end{array}$ & $\begin{array}{l}4 \\
3 \\
3\end{array}$ & $\begin{array}{r}1,270 \\
1,085 \\
690\end{array}$ \\
\hline & Concrete & 3 & 780 \\
\hline \multirow{2}{*}{$\begin{array}{l}\text { Dynamic Tensile Split- } \\
\text { ting Strength (Un- } \\
\text { confined) }\end{array}$} & $\begin{array}{r}\text { Basalt - S } \\
V\end{array}$ & $\begin{array}{l}4 \\
3\end{array}$ & $\begin{array}{l}2,480 \\
1,560\end{array}$ \\
\hline & Concrete & 6 & 1,260 \\
\hline
\end{tabular}

(Continued)

Note: $\mathrm{S}, \mathrm{I}$, and $\mathrm{V}$ represent solid, laminated, and vesicular, respectively. The concrete in the punch-out tests had been cured for 14 days. The concrete in. the other tests had been cured for 21 days.

* This analysis was obtained from "The shear strength of rocks," by R. G. Wuerker, Mining Engineering (October 1959), pp 1022-1026. 


\begin{tabular}{|c|c|c|c|}
\hline Tests & Material & $\begin{array}{l}\text { Number of } \\
\text { Specimens } \\
\text { Tested }\end{array}$ & $\begin{array}{l}\text { Average } \\
\text { Strength } \\
\text { psi } \\
\end{array}$ \\
\hline $\begin{array}{l}\text { Static Shear Strength } \\
\text { (Computed)* }\end{array}$ & $\begin{array}{r}\text { Basalt - S } \\
\text { L } \\
\text { V }\end{array}$ & $\begin{array}{l}-- \\
-- \\
--\end{array}$ & $\begin{array}{l}2,400 \\
1,910 \\
1,210\end{array}$ \\
\hline & Concrete & -- & 1,200 \\
\hline
\end{tabular}

* Computed from Mohr's circle.

2.4.6 Design Approach. The initial assumptions indicated that to prevent the stem from blowing out ahead of the basalt at the time of blast, there must be at least as much shearing resistance between the stem and the in-situ basalt as there is in the basalt. It was evident from the punchout test results that the bond-shear value was greater than the shear. strength for laminated and vesicular basalt, and less for solid basalt. This was to be expected as the solid basalt would produce less bond than the more porous vesicular and laminated types. The ratio of bond strength to shear strength was 1.2 and 1.3 for the laminated and vesicular basalt, respectively.

Applying the design principle of using bond strength to match the shear strength of the medium, it was obvious that no keys were necessary for drill holes 4.0 and 11.0 (fig. Dl) which did not extend to the solid basalt region. However, it was decided that a small reinforced key, $3 \mathrm{ft}$ high and $1.5 \mathrm{ft}$ deep, should be used in each hole because of (a) the possible separation of the stem from the in-situ medium caused by the compression wave of the blast and (b) the unknown effectiveness of the bond in the field due to possible smooth surface or contamination remaining on the bonding surfaces after the drilling operation. Horizontal, radial steel in the keys tended to cause the keys to be overdesigned in shear, but prevented a tensile failure which would have rendered the key and the stem useless. A 20 percent reduction in key area was made to counteract the increased shear resistance.

Drili holes 7.0 and 3.0, which extended into the solid basalt region, required keys to match the shear resistance of the basalt. As in holes 4.0 and 11.0, the superiority of the bond-shear strength over the shear strength of the vesicular and laminated basalt eliminated the necessity 
for design calculations for these strata. The design procedure for matching the shear resistance in the basalt region of holes 7.0 and 3.0 was as follows:

a. Compute the shear resistance of the solid basalt mass based on the circumferential surface area of the access hole in the solid basalt region.

b. Compute the available concrete bond-shear resistance for the same circumferential area.

c. Based on the amount of shear resistance required (computation in a minus computation in $\underline{b}$ ), select the required number of keys.

d. Determine the efficiency of the number of keys used.

e. Determine the compressive strength of the selected concrete mixture and unit resistance (in pounds per square inch) from the MIT report.

f. Determine the required key dimensions using an appropriate formula.

g. Determine amount of steel required to match the tensile strength of the basalt.

h. Check the ultimate static bond resistance of the steel reinforcement.

Design calculations and sketches of the four resulting stems for holes $4.0,11.0,7.0$, and 3.0 are given in Appendix D.

2.4.7 Recommendations. As a result of the laboratory tests conducted and the design approach used in this study, the following stem designs were recommended:

a. Holes 4.0 and 11.0 each should have one key ( $3 \mathrm{ft}$ high and $1.5 \mathrm{ft}$ deep) to resist the tensile stresses perpendicular to the plane of propagation of the compression wave of the blast.

b. Hole 7.0 should have two keys ( $5 \mathrm{ft}$ high and $2 \mathrm{ft}$ deep) to match the shear strength of the solid basalt.

c. Hole 3.0 should have two keys ( $6 \mathrm{ft}$ high and $2 \mathrm{ft}$ deep) to match the shear strength of the solid basalt. 
CHAPTER 3

FIELD WORK

\subsection{SHOTCRETE PLACEMENT}

3.1.1 Equipment. The following equipment was used in the shotcreting operation:

(a) One 360-cu-ft-per-min air compressor (gasoline-operated)

(b) One pneumatic-operated shotcrete apparatus

(c) One conventional 16-cu-ft concrete mixer (gasoline-operated)

3.1.2 Procedure. In order to obtain a relatively smooth surface on the walls of the shot cavities, it was decided to apply a mortar coating as necessary over the rough mined surfaces. The wet-process shotcrete procedure features pneumatically premixed mortar with the water-cement ratio controlled at the mixer. In the method used, the premixed material is fed into a high-velocity airstream and continuously fed to the nozzle at high velocity. Air pressure was also provided at the nozzle to give an additional boost to the material; however, the nozzle booster is not necessarily required, due to the high-velocity airstream conveying the materials.

Since there were no experienced nozzlemen available, it was decided that the nozileman designated for the placement of the shotcrete mixture should experiment with the equipment using the designed mixture on the ground surface. The equipment was set up for operation with about $75 \mathrm{ft}$ of delivery hose laid out on the ground. It was found that a mixture having less than a 4-in. slump would cause stoppages within the delivery hose. However, when the nozzle and delivery hose were lowered into the cavity, the equipment operated satisfactorily in pumping the designed mixture having a 3-in. slump. When the slump of the mixture was decreased to less than 3 in., stoppages occurred within the delivery hose. When the slump of the mixture was increased beyond 3-1/2 in., the mixture did not adhere satisfactorily to the walls of the cavity.

A layer of wire mesh was installed around the periphery of the cavity to help hold the mixture when it was applied and to provide tensile strength. Grade templates were set at the finish grades of the shotcrete walls to assist the operator in securing desired grade. The shotcrete 
was mixed in a conventional 16-cu-ft concrete mixer. The mixer and grouter setup is shown in fig. 2. The mixture was applied in layers 1 to 2 in. thick at rates of 1 to $2 \mathrm{cu}$ ft per min. Each layer was allowed to reach its initial set, and then another layer was applied. Fig. 3 shows the wall of a cavity after some shotcrete had been applied. Due to the length of time allowed for the shotcreting of holes 3.0 and 11.0 , it was necessary to use an accelerator in the shotcrete mixture. When this mixture (shotcrete mixture 2) was used, layers of shotcrete could be placed almost immediately after the completion of the placement of the preceding layer. The proportions for this mixture are given in table 1 . Shotcrete mixture 1 was used in holes 7.0 and 4.0, and shotcrete mixture 2 was used in holes 3.0 and 11.0 .

\subsection{GROUTING}

3.2.1 Equipment. The following major items of equipment were used in the grouting operations:

(a) One 125-cu-ft-per-min air compressor (gasoline-operated)

(b) One positive-displacement grout pump (air-operated)

(c) One 5-cu-ft-capacity, tub-type grout mixer (air-operated)

3.2.2 Procedure. Three NX-diameter holes at radial distances of 35 ft from ground zero and angles of $120 \mathrm{deg}$ were drilled at each detonation site. Colored steel tapes $80 \mathrm{ft}$ long and serrated at 6-in. intervals were placed in these holes. A l-in.-ID, plastic, grout-injection hose was lowered into each hole, and the hoses were withdrawn as grout was pumped into the holes. Information on the color of tapes and grouts in each of the holes is given in table 2. Minor "lost circulation" difficulties which are considered normal in field grouting were experienced, but all holes were filled to the surface as required through the use of stage grouting procedures; introducing sand plugs as the grouting progressed.

\subsection{CONCRETE PLACEMENT}

3.3.I Equipment. The following equipment was utilized in the placement of stemming concrete:

(a) One drum-type, 16-cu-ft-capacity concrete mixer (gasolineoperated) 


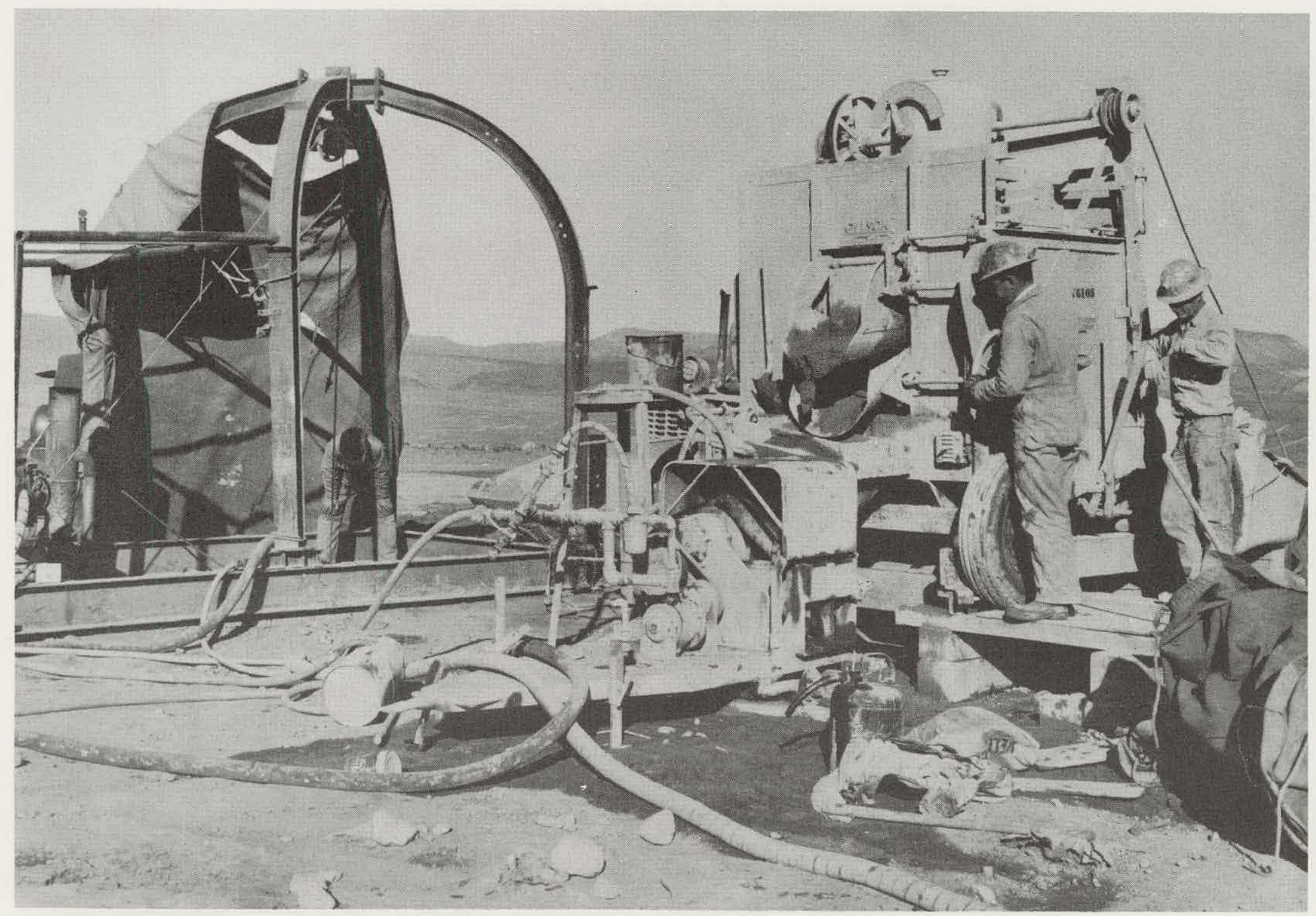

Fig. 2. Shotcrete mixer and grouter 


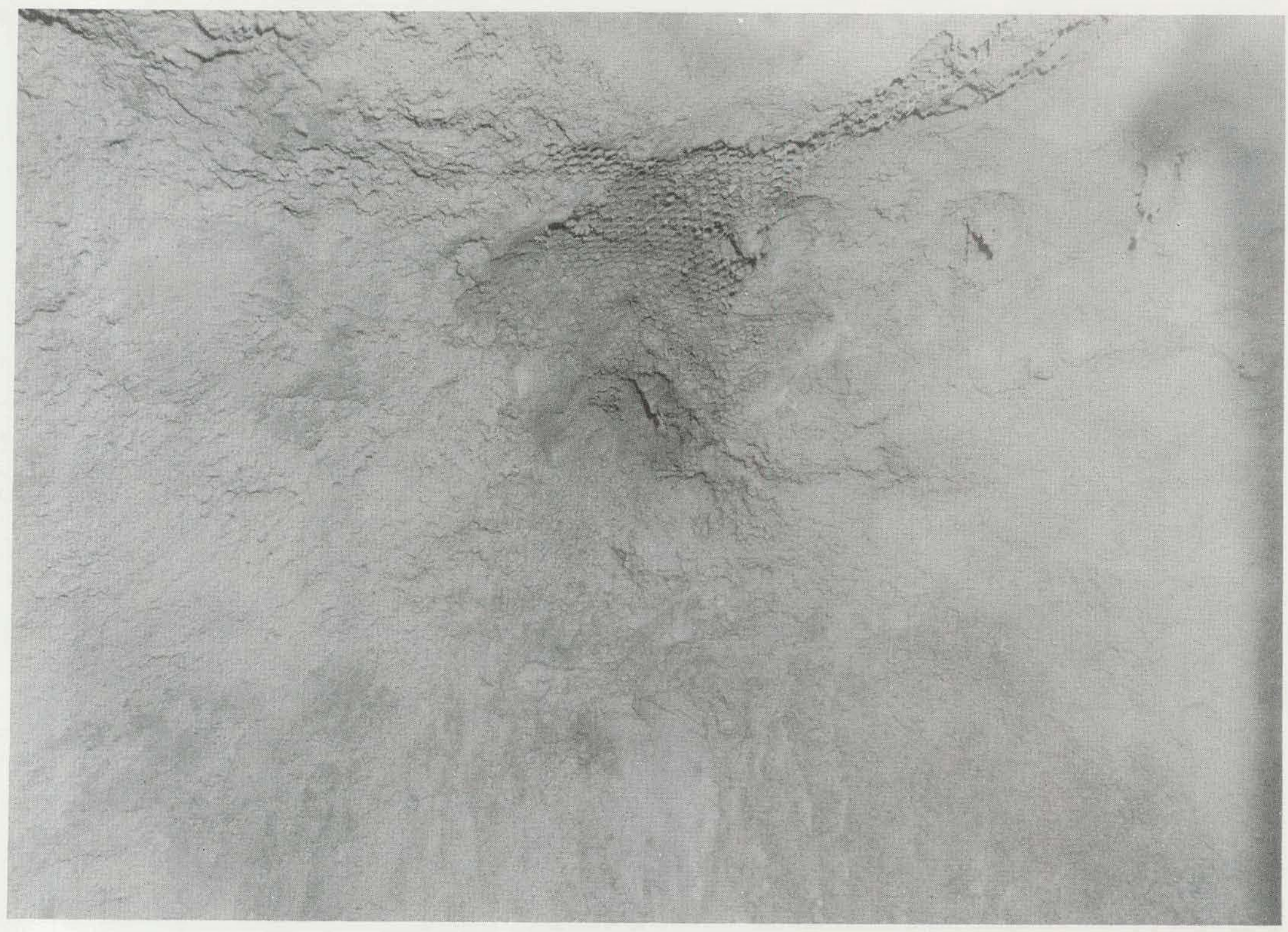

Fig. 3. Cavity wall after partial covering with shotcrete 
(b) One sectional metal tremie (approximate ID $=6$ in.)

(c) One electric, short-nose vibrator (1-1/2-in.-diameter head)

3.3.2 Procedure. After the shotcreting operation was completed, each cavity was painted with a liquid plastic compound for additional precaution against loss of the chemical explosive through the cavity wall. The booster charge was placed in the center of the spherical cavity, and the access hole was sealed with a metal cover at the top of the cavity.

The following procedure was utilized in the placement of the stems:

a. The required reinforcing steel was placed in the keys and tied in place.

b. An initial approximately 5-ft lift of concrete was mixed, placed as support for the remainder of the stem, and allowed to set for $48 \mathrm{hr}$.

c. The second lift of the concrete stem was mixed and placed. The concrete mixture was mixed in a conventional 16-cu-ft concrete mixer and placed in each hole by means of a tremie to avoid undesirable segregating of aggregates. The metallic aggregate was not used in the concrete of the first lift as a precaution against possible metallic contamination in the chemical explosive charge in the cavity. Consolidation was effected by lowering a man into the keyways who used an electric vibrator to consolidate the concrete as it was placed through the tremie. When the concrete level reached the keyway, the man was hoisted out of the keyway and consolidation was effected by lowering the vibrator to the concrete with a rope. Fig. 4 shows the tremie being lowered into place to receive the concrete.

The concrete was colored with various colors at different depths, as shown in table 3 , to aid in postshot identification of recovered pieces of stem. Slump tests and compression tests on cast cylindrical specimens were made on representative batches from each stem-placing operation to check the consistency and quality of the concrete. 


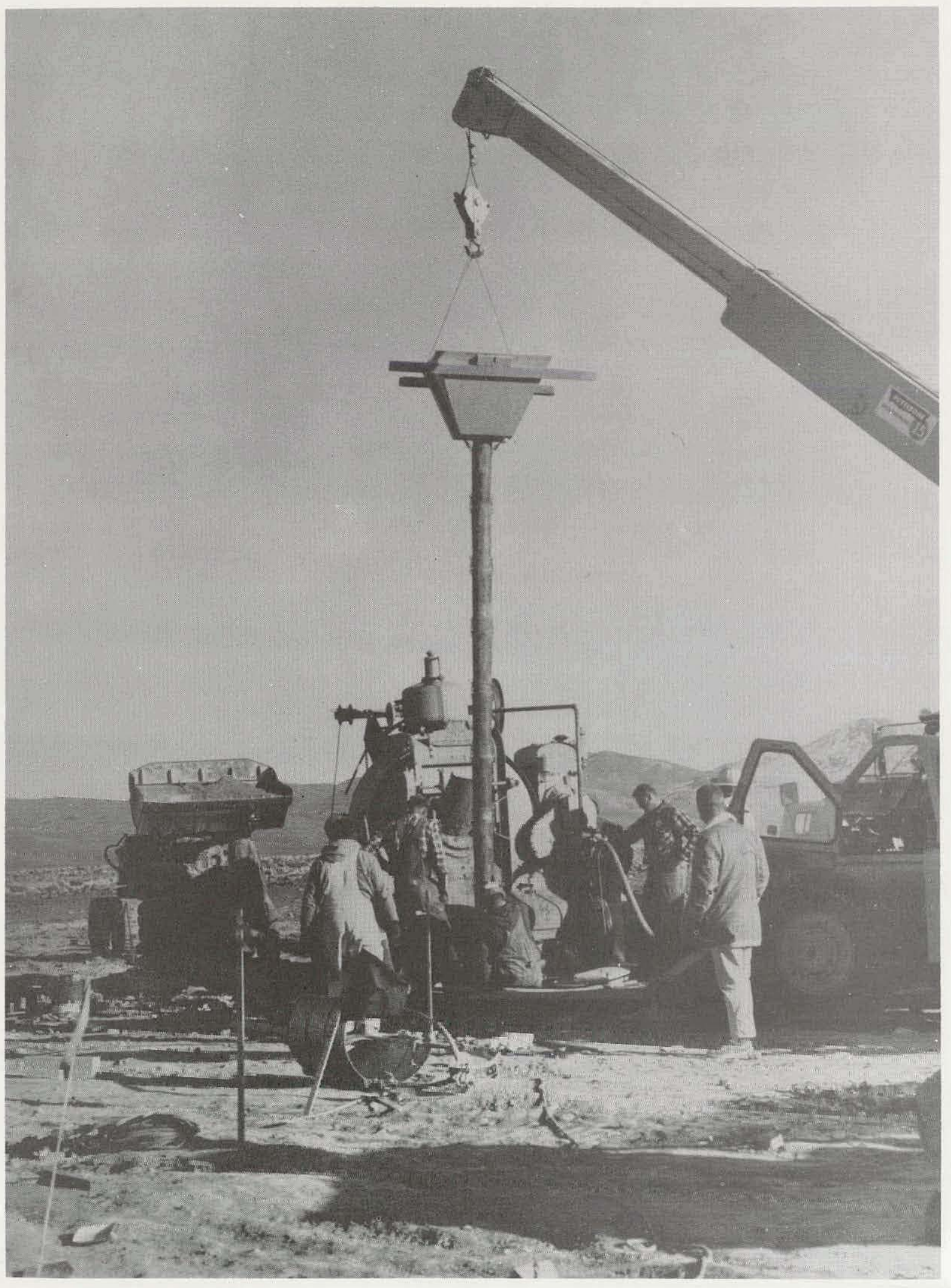

Fig. 4. Lowering of tremie used in concrete placement 
Table 2

Color of Grout and Tape in Holes

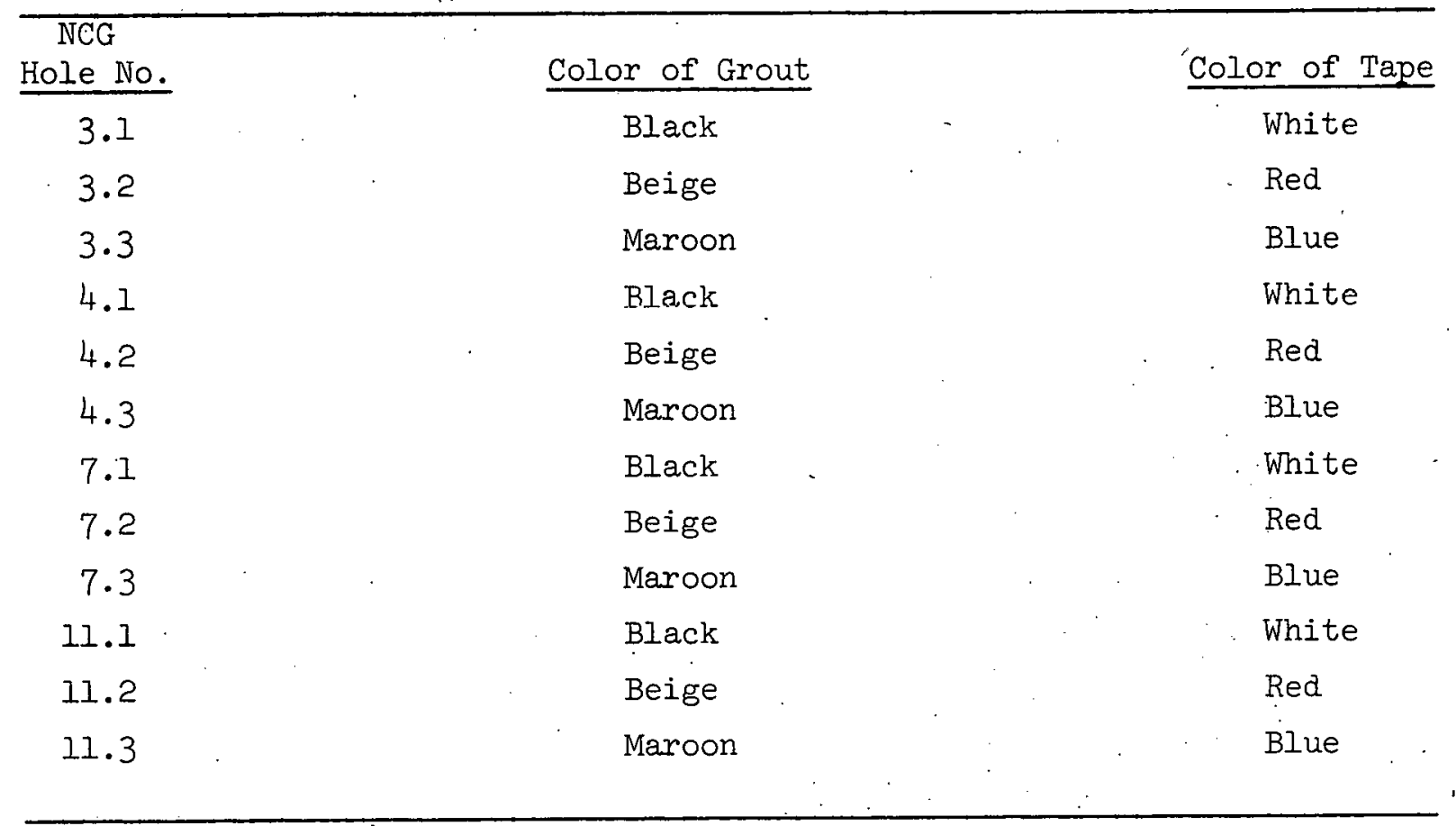

Table 3

Stem Colors at Various Depths

\begin{tabular}{|c|c|c|c|c|}
\hline NVCG & \multicolumn{4}{|c|}{ Depth Below Ground Surface, ft } \\
\hline Hole No: & Yellow & Terra cotta & Green & Brown \\
\hline 7.0 & $45.5-52.3$ & $33.0-45.5$ & $16.0-33.0$ & $0-16.0$ \\
\hline 4.0 & $39.0-44.3$ & $25.0-39.0$ & $12.0-25.0$ & $0-12.0$ \\
\hline 3.0 & $50.0-60.3$ & $35.0-50.0$ & $16.0-35.0$ & $0-16.0$ \\
\hline 11.0 & $26.0-36.3$ & $18.0-26.0$ & $9.0-18.0$ & $0-9.0$ \\
\hline
\end{tabular}


CHAPTER 4

TEST RESULTS, DISCUSSION; AND CONCLUSIONS

\subsection{SHOTCRETE}

In order to check the efficiency of the field shotcreting operation, 2-in. cubes of representative shotcrete batches were cast, sent to the WES laboratory, and tested for compressive strength on the detonation date of each shot. Results are given in table 4. The specimens from holes 7.0 and 4.0 had a very acceptable compressive strength of approximately 8000 psi. The accelerator used in the mixture for holes 3.0 and 11.0 necessitated the use of additional water to maintain the 3 -in. slump. The additional water reduced the compressive strength to approximately 5500 psi. The functional efficiency of the shotcrete lining could only be judged by impermeability with regard to leakage of the chemical explosive through. the lining. In this respect, the shotcrete lining was considered to have performed satisfactorily, as no leakage was detected in any of the four shot emplacements.

\subsection{GROUT}

Postshot excavation of the cavities or postshot redrilling of the radial holes will determine if the grout served the desired purpose of containing the serirated tapes and acting as the surrounding medium in the cratering phenomena. Results of density, ultrasonic pulse velocity, and compressive strength tests are given in table 4. The grout density values obtained for all holes were acceptable. With the exception of the grout in holes 7.1, 7.2, and 7.3, which was only seven days old at time of test, the ultrasonic pulse: velocities were within the desired range for all holes. The compressive strength test results are considered satisfactory for fieldmixed grout with the consistency required.

\subsection{CONCRETE}

Test results in table 4 indicate that quality concrete was obtained on the job, as all design requirements (density = $165 \mathrm{Ib}$ per cu ft, pulse velocity $=14,000 \mathrm{fps}$, and compressive strength $=7000 \mathrm{psi}$ ) were met. Actually the field mixture was probably rich compared to the laboratorydesigned mixture, due to the tendency in the field to be conservative with 
the aggregate and liberal with the cement. This was the result of mixing batch ingredients by volume rather than weight, necessitated by the inability of the support contractor to furnish scales.

\subsection{STEMS}

In order to more closely establish the behavior of the stems in the four shots, a postshot field examination was conducted. It was believed that a comparison of stem ejecta with basalt ejecta would indicate the effectiveness of the stem. Factors of the basalt and the stem that were most closely examined for comparison were crack pattern, bond, and particle size. The failure modes of both the stem and the steel embedded in the keys were also examined.

Buckboard Mesa was partially covered with snow at the time of the postshot stem evaluation, which made locating the small stem particles and pieces of steel difficult. In some instances, no steel and very few pieces of the stem could be found. This was partially due to burial of the steel and stem pieces by basalt ejecta, but to what extent the material was buried was impossible to determine.

4.4.i Site Alfa. There were good examples of stem ejecta at site Alfa ranging from whole portions of full diameter and approximately $3 \mathrm{ft}$ in height to small rubble (fig. 5). Tensile spalling seemed to account for a large portion of the stem failure. Some stem pieces were fractured longitudinally with irregular end breaks. The smallest pieces of the stem were yellow and terra cotta arid, in some cases, could be crumbled by hand. Where stem faces were intact, they were mostly smooth. Steel was found in lengths ranging from 3 in. up to $2 \mathrm{ft}$, and evidence of high stresses was found in nearly all cases (fig. 6). Some steel showed evidence of the action of high temperature. Fracture surfaces of the steel pieces showed clean vertical breaks (probably shear), highly irregular angular breaks with "necking" evident near the break, deep scoring indentions (unexplained), and general. evidence of violent forces upon the steel. Some steel was found still embedded in portions of the key. One piece of yellow-colored stem ( $f i g .6$ ) with steel bars still in place was extensively cracked, indicating that a compressive failure had probably occurred in the lower stem area. Basalt ejecta was widely scattered and 
Table 4

Results of Tests on Field-Mixed Shotcrete, Grout, and Concrete Specimens

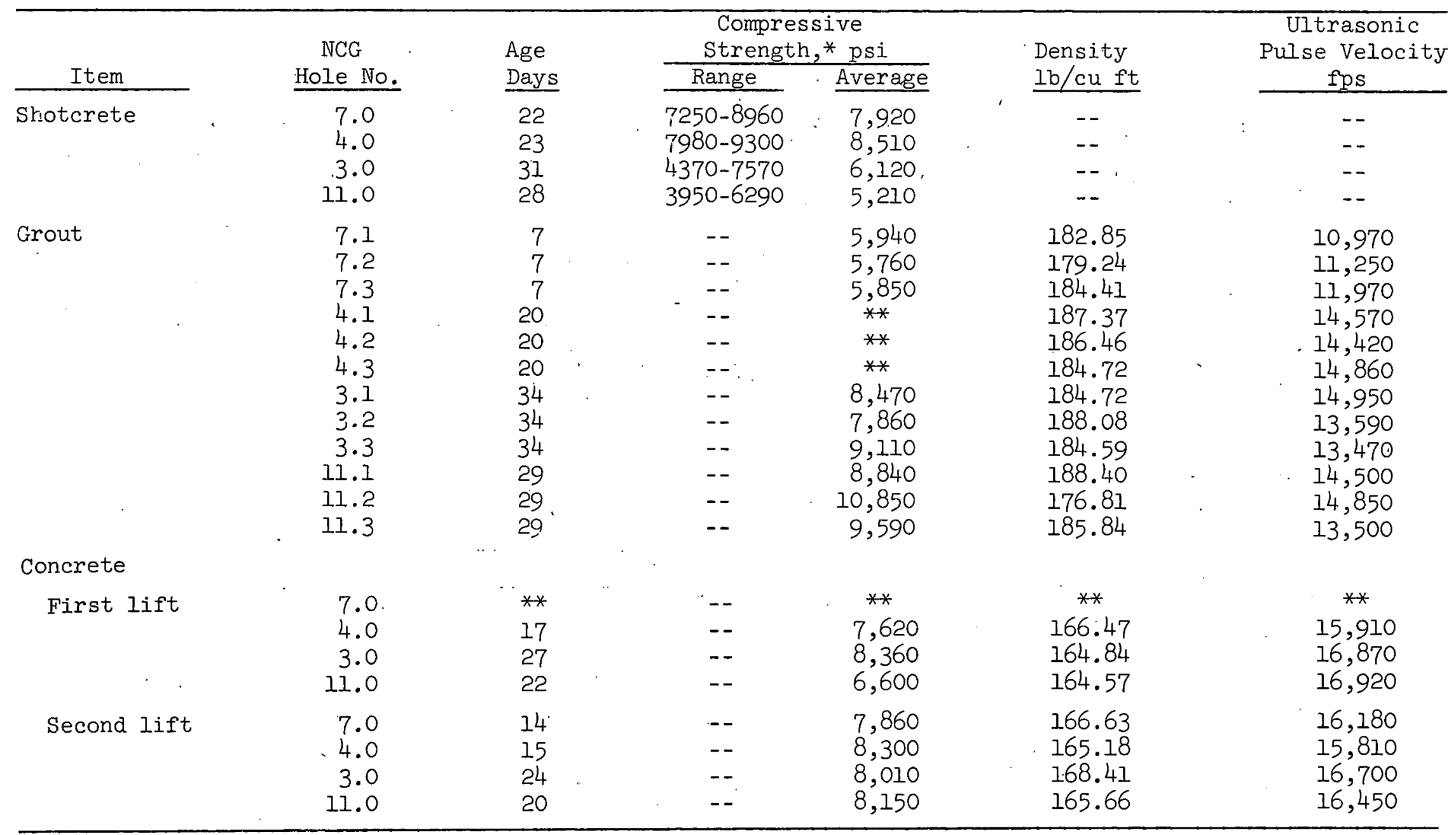

* Compressive strength was determined on 18 shotcrete specimens for each hole, 1 grout specimen for each hole, and 4 concrete specimens for each hole.

* Specimens broken in handling. 


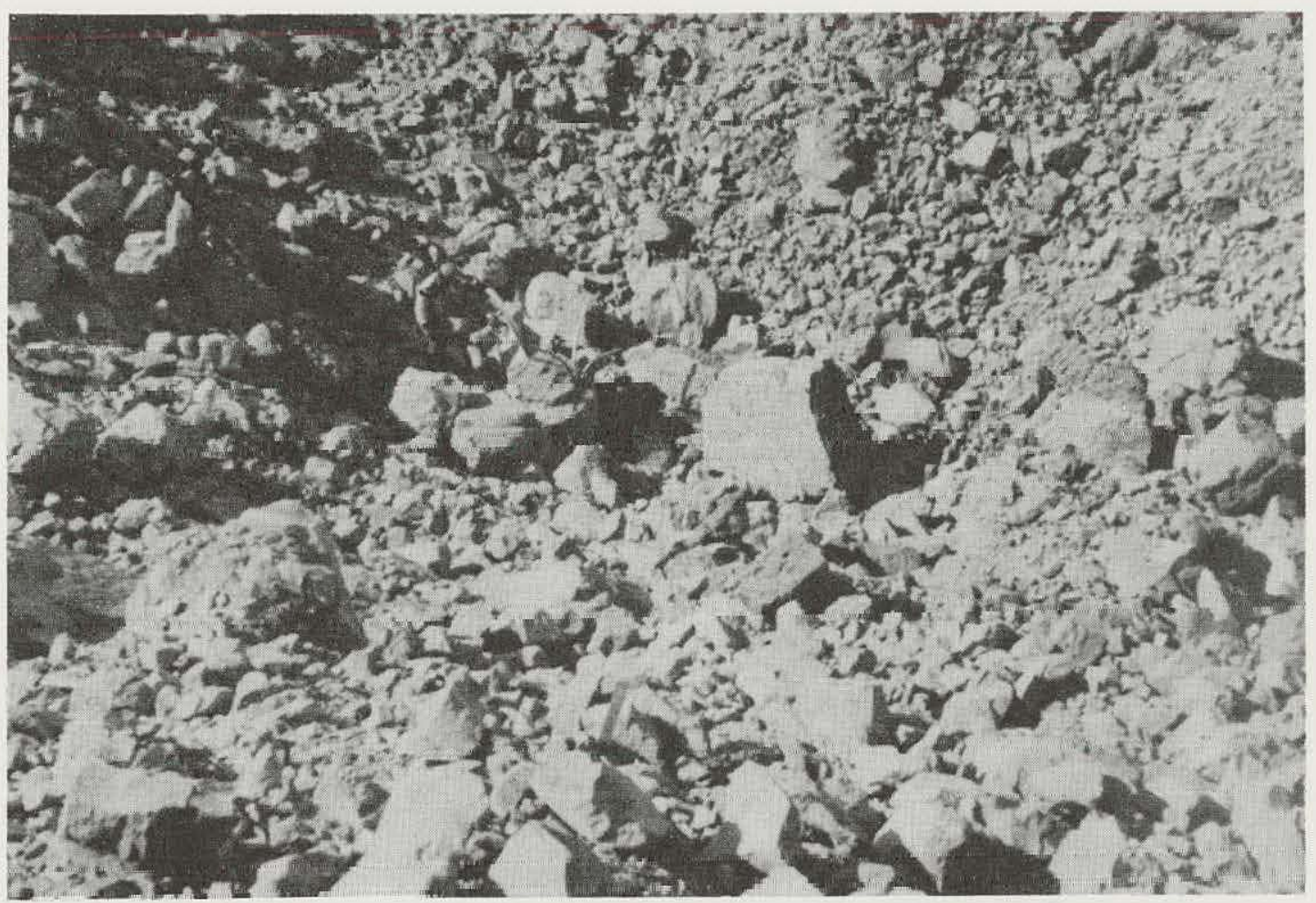

Fig. 5. Alfa crater. Note stem collar near center of picture

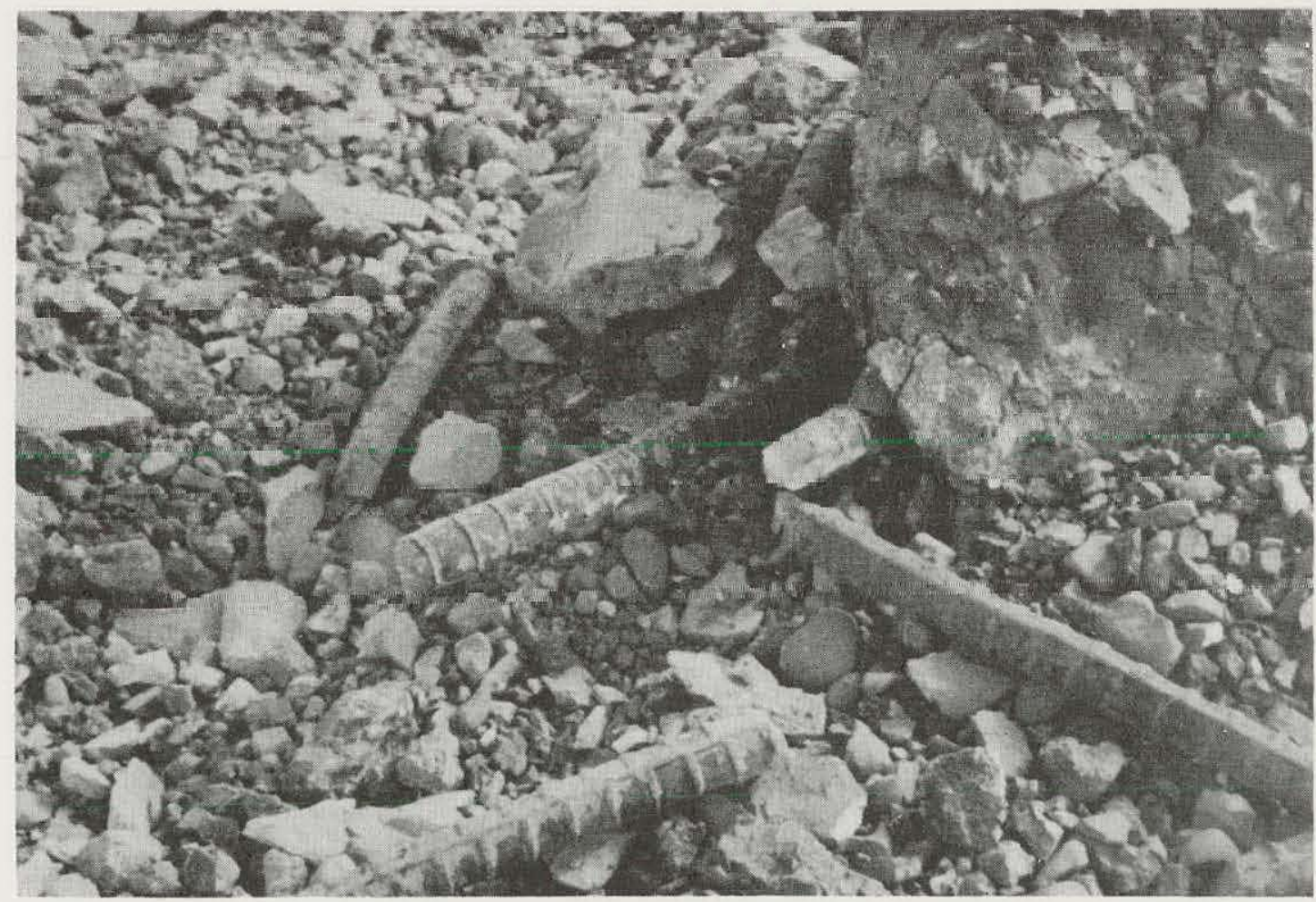

Fig. 6. Reinforcing steel and piece of concrete (upper right) from Alfa stem 
ad a wide range of paticle size. The top collar of the stem had fallen back into the crater (fig. 5). This site gave the most extensive information on stem behavior and ejecta.

4.4.2 Site Bravo. This site had a very wide distribution of basalt ejecta. A few large green pieces and one large terra cotta piece of the stem were found. Smaller particles were found sparsely distributed about $200 \mathrm{ft}$ from the crater rim. No portion of the stem was found in the crater. One piece of steel was found with an apparent, shear break at one end.

4.4.3 Site Char7ie. The detonation at this site resulted in a rubble mound type of crater. A few quite large pieces of stem were found. The top collar was found $100 \mathrm{ft}$ from the crater and had 2-1/2 ft of the stem still attached below it. The presence of a large amount of clay in the surrounding medium was shown by the clay-filed seams in the ejecta. A few pieces of steel were found that resembled those found in the Alfa area. A brown piece of stem was found with basalt still attached to it. The basalt ejecta was distributed over a small area.

4.4.4 Site Delta. At this site, basalt ejecta was extensively distributed in a wide range of sizes, as is characteristic of a burst at a shallow depth below the ground surface. The collar of the stem was located. A few pieces of yellow and terra cotta stem were found which had a maximum size of $10 \mathrm{in.} \mathrm{No} \mathrm{steel} \mathrm{was} \mathrm{found.}$

4.4.5 Summary. It is concluded from tests at site Alfa that the stem performed its intended function. It appeared to have failed at the same time as, and in a like manner to, the surrounding basalt at detonation. Comparative particle sizes, ejecta distribution, and modes of failure of the stem and the basalt substantiated this belief. The postshot condition of the steel that was embedded in the keys indicated that the steel apparently performed its resistance function well. This was shown by the failure modes (shear and tension). Indications were that the lower portion of stem Alfa (possibly from the key down) failed in compression. Postshot surveys at other sites added evidence to the belief that the stems were efrective as designed, although the evidence was not as extensive as at site Alfa. Excessive fragmentation at site Delta did not correspond exactly with the basalt fragmentation, but there was probably not a significant disparity. In general, it was believed that the stems performed their intended 
purpose, and if further shots are conducted in similar materials, similar stem design procedures could be used with reasonable certainty of adequate results. 
APPENDIX A: SPECIAL EQUIPMENT 


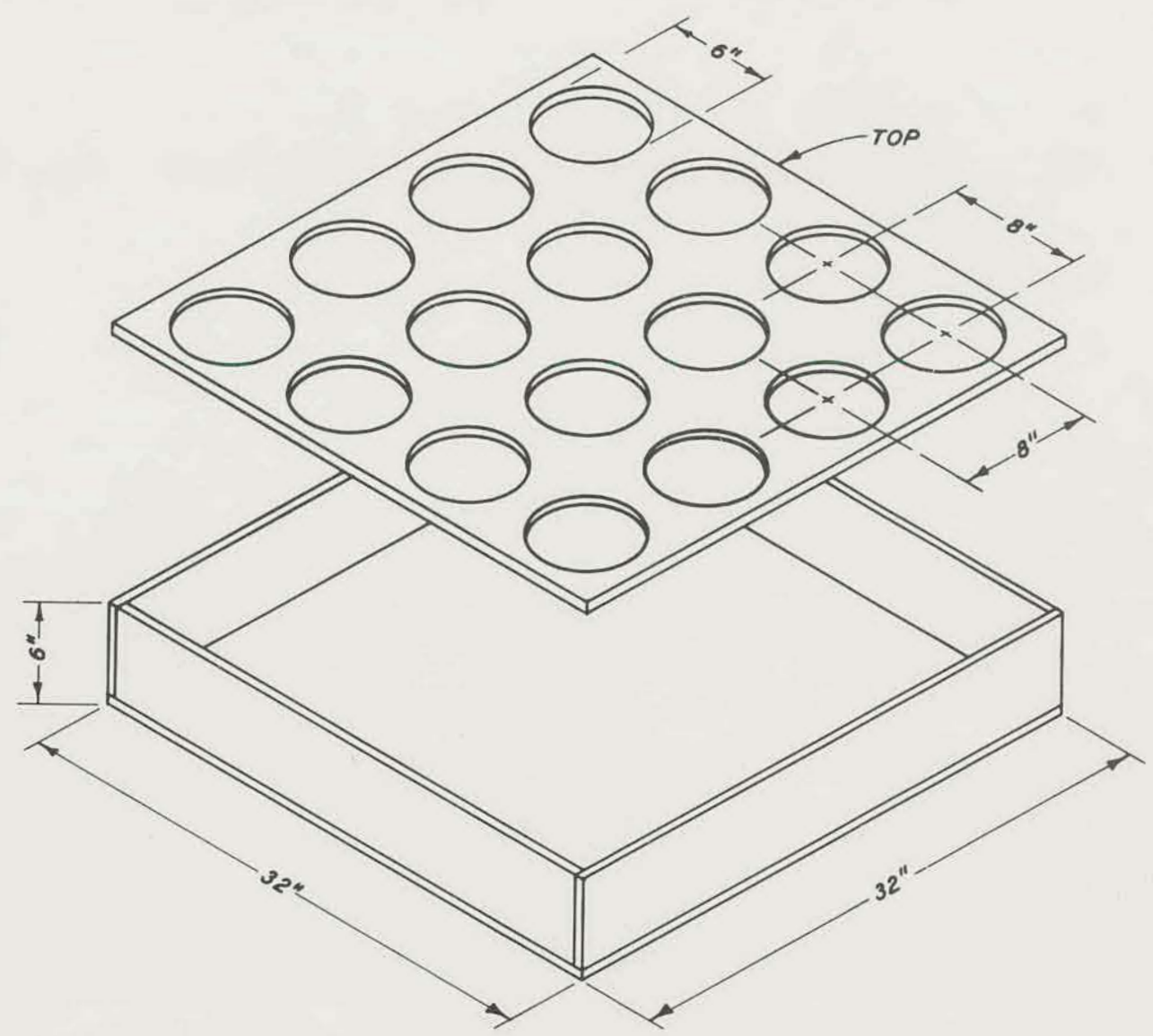

Fig. Al. Frames in which basalt specimens were grouted to stabilize the specimens during drilling of 3-in.-diameter hole in center of each specimen

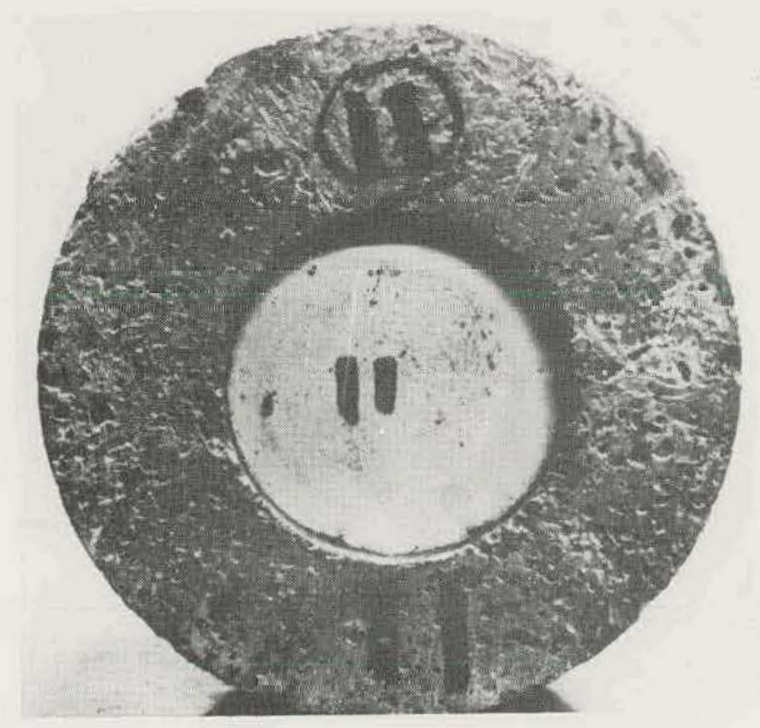

a. Top view showing hydrostone cap on concrete filler

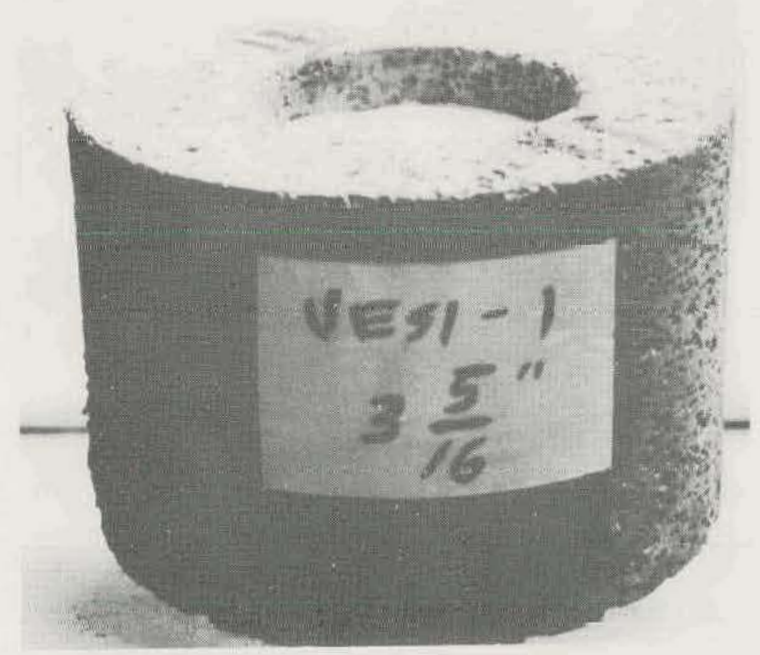

b. Side view $(3-5 / 16$ corresponds to the height in inches of concrete filler from the base to the cap) 


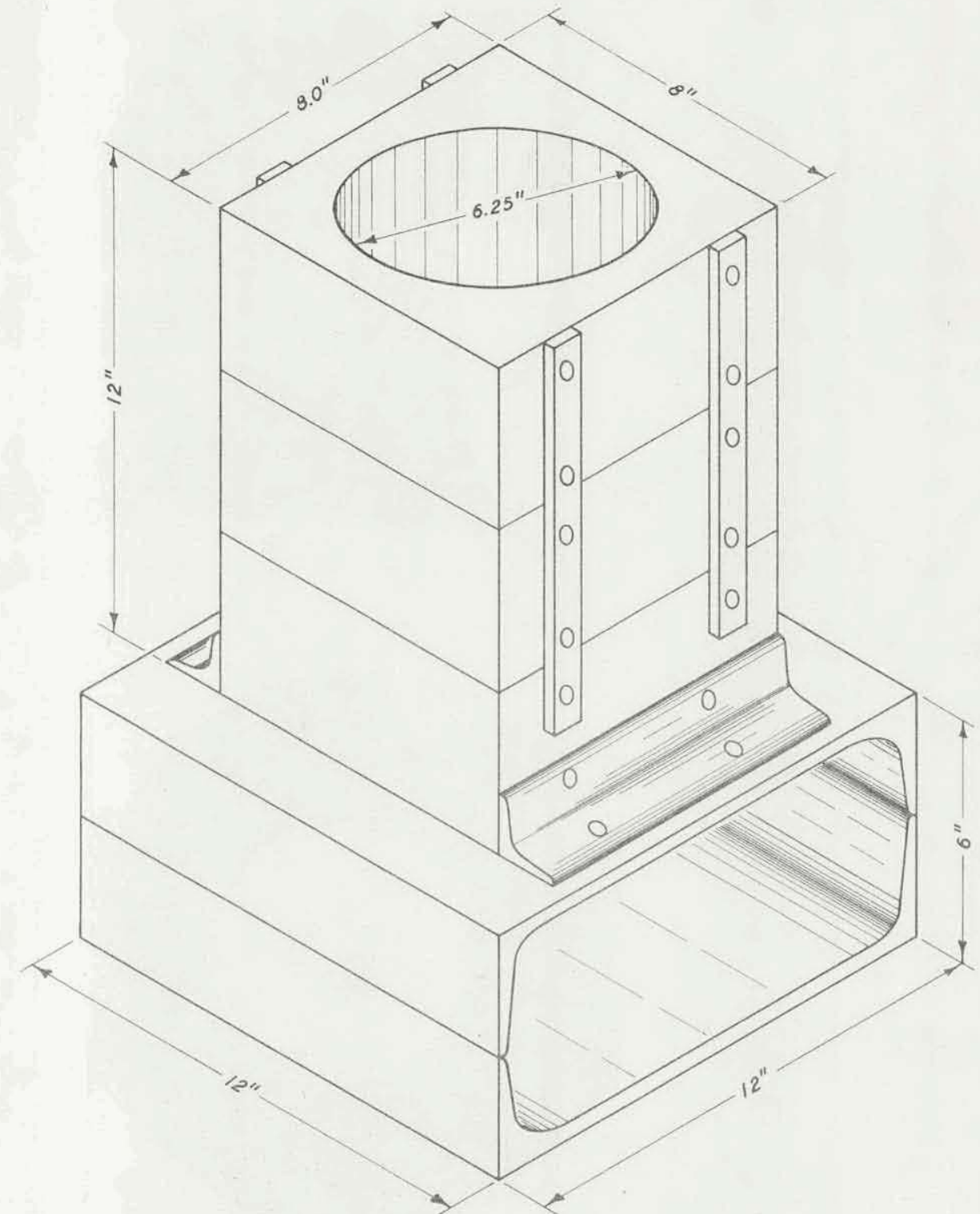

Fig. A3. Punch-out testing frame

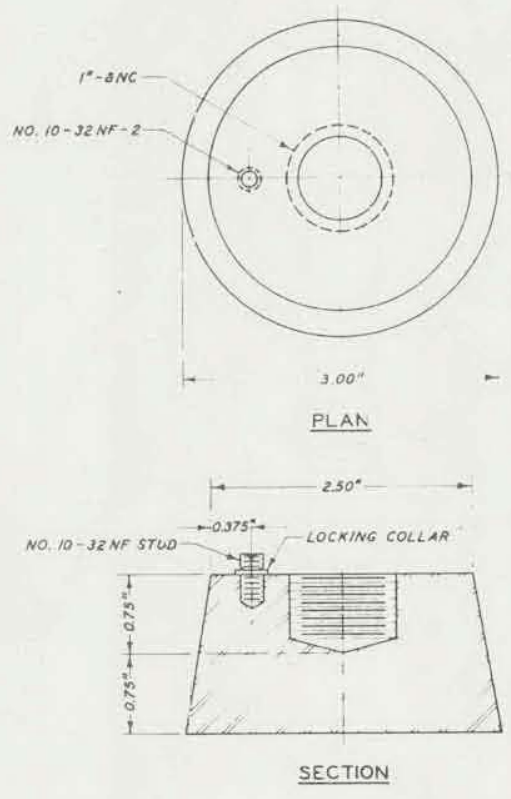

Fig. A4. Punch-out piston 


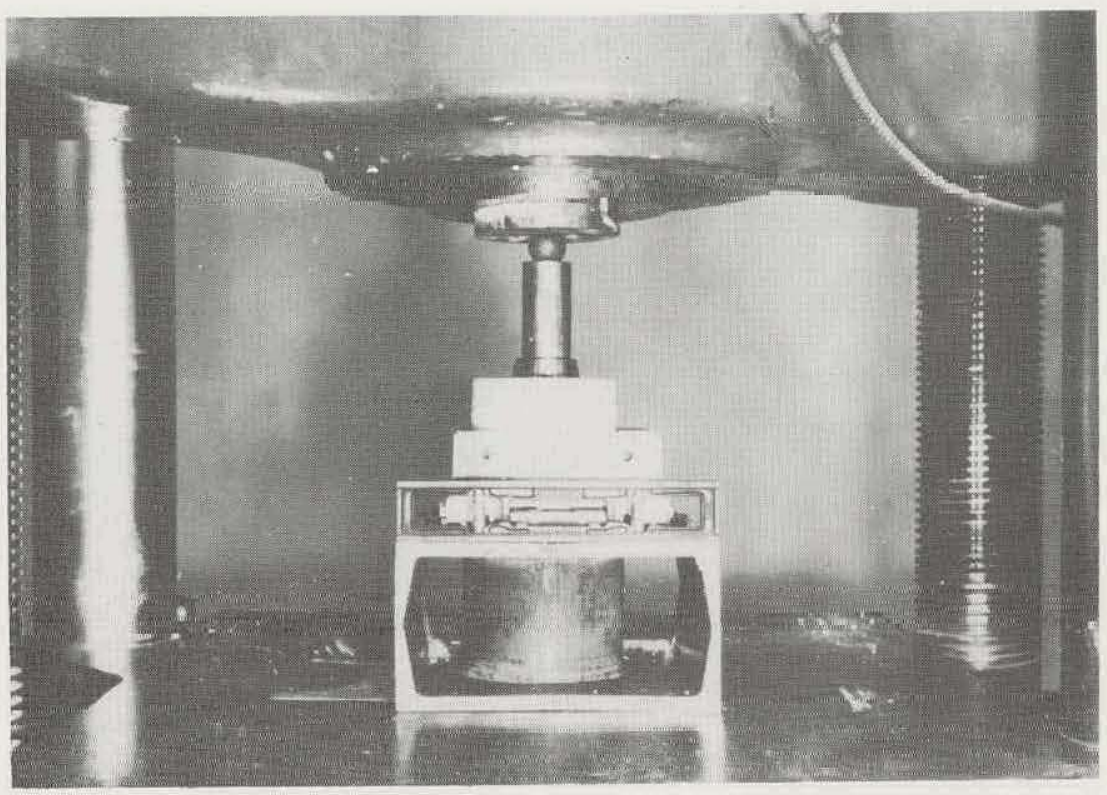

Fig. A5. Loading apparatus for punch-out tests with specimen in place 
APPENDIX B: : MOHR'S CIRCLE ANALYSIS 
The following Mohr's circle analysis is for the determination of the shear strength of any material by using the tensile and compressive strengths. Terms used in the algebraic analysis are illustrated in Fig. Bl.

F'ig. Bl. Mohr's circles for determining shear.strength $v$ by using tensile strength. $\sigma_{t}$ and compressive strength $\sigma_{c}$

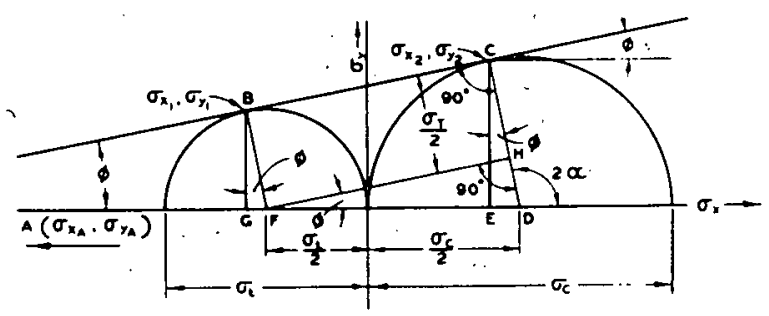

1. $\frac{F D}{\mathrm{HD}}=\frac{\mathrm{AD}}{\mathrm{CD}}$

2. $F D=\frac{\sigma_{t}+\sigma_{c}}{2}$

3. $\mathrm{CD}=\frac{\sigma_{\mathrm{C}}}{2}$

4. ${ }^{\prime} H D=\frac{\sigma_{c}-\sigma_{t}}{2}$

5. $\frac{\frac{\sigma_{t}+\sigma_{c}}{2}}{\frac{\sigma_{c}-\sigma_{t}}{2}}=\frac{A D}{\frac{\sigma_{c}}{2}}$

6. $\frac{\sigma_{c}}{2}\left(\frac{\sigma_{t}+\sigma_{c}}{\sigma_{c}-\sigma_{t}}\right)=A \dot{D}=\frac{\sigma_{c}^{2}+\sigma_{t} \sigma_{c}}{2\left(\sigma_{c}-\sigma_{t}\right)}$

7. $\frac{E D}{C D}=\sin \varnothing=\frac{C D}{A D}$

8. $\mathrm{ED}=\frac{(\mathrm{CD})^{2}}{\mathrm{AD}}=\frac{\frac{\sigma^{2}}{4}}{\frac{\sigma_{c}\left(\sigma_{c}+\sigma_{t}\right)}{2\left(\sigma_{c}-\sigma_{t}\right)}}$ 
9. $\quad \mathrm{ED}=\frac{\sigma_{c}\left(\sigma_{c}-\sigma_{t}\right)}{2\left(\sigma_{c}+\sigma_{t}\right)}$

10. $\frac{\sigma_{c}}{2}-\mathrm{ED}=\sigma_{\mathrm{x}_{2}}=\frac{\sigma_{c}}{2}\left(1-\frac{\sigma_{c}-\sigma_{t}}{\sigma_{c}+\sigma_{t}}\right)$

11. $\sigma_{x_{A}}=A D-\frac{\sigma_{C}}{2}=\frac{\sigma_{C}}{2}\left(\frac{\sigma_{c}+\sigma_{t}}{\sigma_{c}-\sigma_{t}}-1\right)$

12. $\sigma_{\mathrm{y}_{\mathrm{A}}}=0$

13. $\operatorname{Cos} \varnothing=\frac{E C}{C D}=\frac{F H}{F D}$

14. $(\mathrm{FH})^{2}+(\mathrm{HD})^{2}=(\mathrm{TD})^{2}$

Rearranging and substituting,

15. $F H=\sqrt{\left(\frac{\sigma_{t}+\sigma_{c}}{2}\right)^{2}-\left(\frac{\sigma_{c}-\sigma_{t}}{2}\right)^{2}}$

16. $F H=\frac{1}{2} \sqrt{\sigma_{t}^{2}+2 \sigma_{t} \sigma_{c}+\sigma_{c}^{2}-\sigma_{c}^{2}+2 \sigma_{c} \sigma_{t}-\sigma_{t}^{2}}$.

17.. $\mathrm{FH}=\sqrt{\sigma_{c} \sigma_{\mathrm{t}}}$

Substituting,

18. $F C=\frac{\sigma_{c} \sqrt{\sigma_{c} \sigma_{t}}}{\sigma_{c}+\sigma_{t}}=\sigma_{y_{2}}$

For a straight line,

19. $\sigma_{y}=M \sigma_{x}+v$

where

$$
\mathrm{iM}=\text { slope of line }
$$

or

20. $\frac{\sigma_{\mathrm{y}}-\sigma_{\mathrm{y}_{\mathrm{A}}}}{\sigma_{\mathrm{y}_{2}}-\sigma_{\mathrm{y}_{\mathrm{A}}}}=\frac{\sigma_{\mathrm{x}}-\sigma_{\mathrm{x}_{\mathrm{A}}}}{\sigma_{\mathrm{x}_{2}}-\sigma_{\mathrm{x}_{\mathrm{A}}}}$

B2 
As previously stated,

21. $\sigma_{x_{A}}, \sigma_{y_{A}}=\frac{\sigma_{c}}{2}\left(\frac{\sigma_{c}+\sigma_{t}}{\sigma_{c}-\sigma_{t}}-1\right), 0$

and

22. $\sigma_{x_{2}}, \sigma_{y_{2}}=\frac{\sigma_{c}}{2}\left(1-\frac{\sigma_{c}-\sigma_{t}}{\sigma_{c}+\sigma_{t}}\right), \frac{\sigma_{c} \sqrt{\sigma_{c} \sigma_{t}}}{\sigma_{c}+\sigma_{t}}$

$\sigma_{\mathrm{x}_{\mathrm{A}}}$ will now be employed with its graphical sign, i.e. minus.

Substituting,

23. $\frac{\sigma_{y}-0}{\sigma_{x}+\frac{\sigma_{c}}{2}\left(\frac{\sigma_{c}+\sigma_{t}}{\sigma_{c}-\sigma_{t}}-1\right)}$

$\frac{\sigma_{c} \sqrt{\sigma_{c} \sigma_{t}}}{\sigma_{c}+\sigma_{t}}-0 \frac{\sigma_{c}}{2}\left(1-\frac{\sigma_{c}-\sigma_{t}}{\sigma_{c}+\sigma_{t}}\right)+\frac{\sigma_{c}}{2}\left(\frac{\sigma_{c}+\sigma_{t}}{\sigma_{c}-\sigma_{t}}-1\right)$

$24 \cdot \sigma_{y}\left(\frac{\sigma_{c}+\sigma_{t}}{\sigma_{c} \sqrt{\sigma_{c} \sigma_{t}}}\right)=\frac{\sigma_{x}+\frac{\sigma_{c}}{2}\left(\frac{2 \sigma_{t}}{\sigma_{c}-\sigma_{t}}\right)}{\frac{\sigma_{c}}{2}\left(\frac{4 \sigma_{t} \sigma_{c}}{\sigma_{c}^{2}-\sigma_{t}^{2}}\right)}$

25. $\sigma_{y}\left(\frac{\sigma_{c}+\sigma_{t}}{\sigma_{c} \sqrt{\sigma_{c} \sigma_{t}}}\right) \frac{\sigma_{c}}{2}\left(\frac{4 \sigma_{t} \sigma_{c}}{\sigma_{c}^{2}-\sigma_{t}^{2}}\right)=\sigma_{x}+\sigma_{c}\left(\frac{\sigma_{t}}{\sigma_{c}-\sigma_{t}}\right)$

26. $\sigma_{y}\left(\frac{2 \sqrt{\sigma_{t} \sigma_{c}}}{\sigma_{c}-\sigma_{t}}\right)=\sigma_{x}+\frac{\sigma_{c} \sigma_{t}}{\sigma_{c}-\sigma_{t}}$

Simplifying,

27. $\sigma_{\mathrm{y}}=\sigma_{\mathrm{x}}\left(\frac{\sigma_{\mathrm{c}}-\sigma_{t}}{2 \sqrt{\sigma_{t} \sigma_{c}}}\right)+\left(\frac{\sigma_{c} \sigma_{t}}{\sigma_{c}-\sigma_{t}}\right)\left(\frac{\sigma_{c}-\sigma_{t}}{2 \sqrt{\sigma_{t} \sigma_{c}}}\right)$

28. $\sigma_{y}=\sigma_{x}\left(\frac{\sigma_{c}-\sigma_{t}}{2 \sqrt{\sigma_{c} \sigma_{t}}}\right)+\frac{\sqrt{\sigma_{c} \sigma_{t}}}{2}$

B3 
Thus, it is apparent that $v=\frac{\sqrt{\sigma_{c} \sigma_{t}}}{2}$

A graphic analysis is illustrated in fig. B2. 


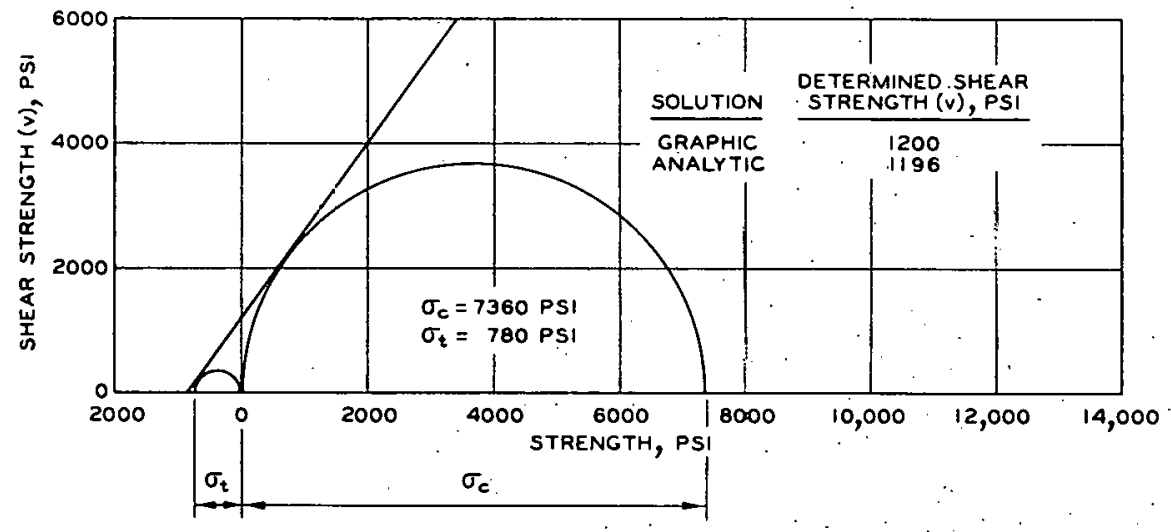

a. STEMMING CONCRETE MIXTURE

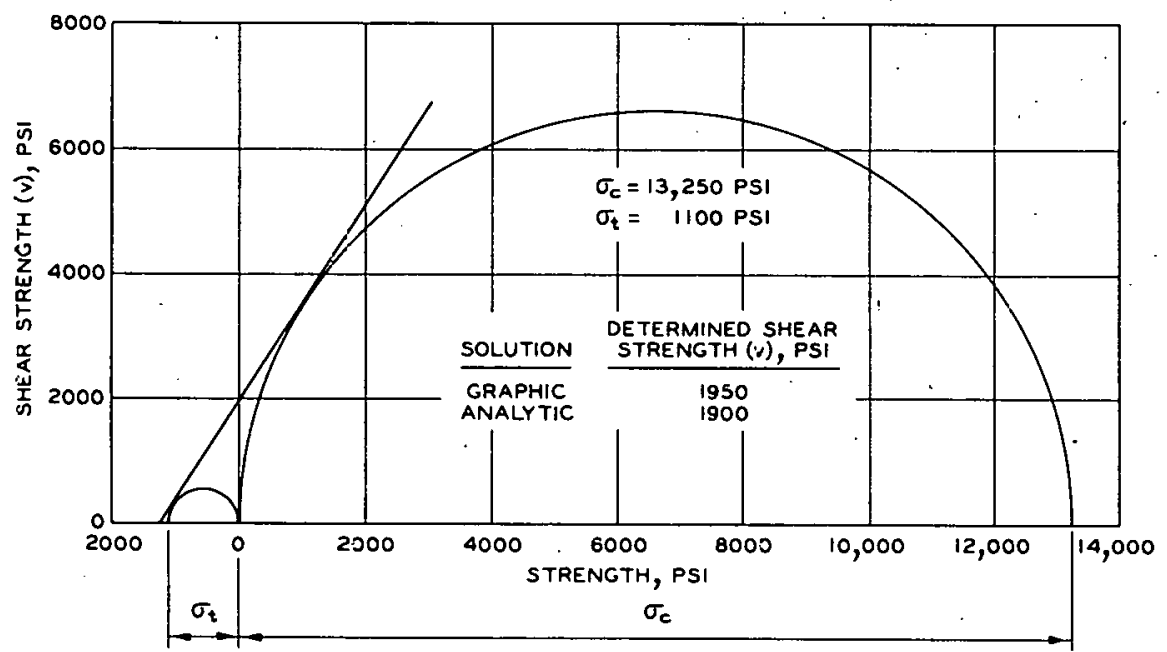

c. LAMINATED BASALT

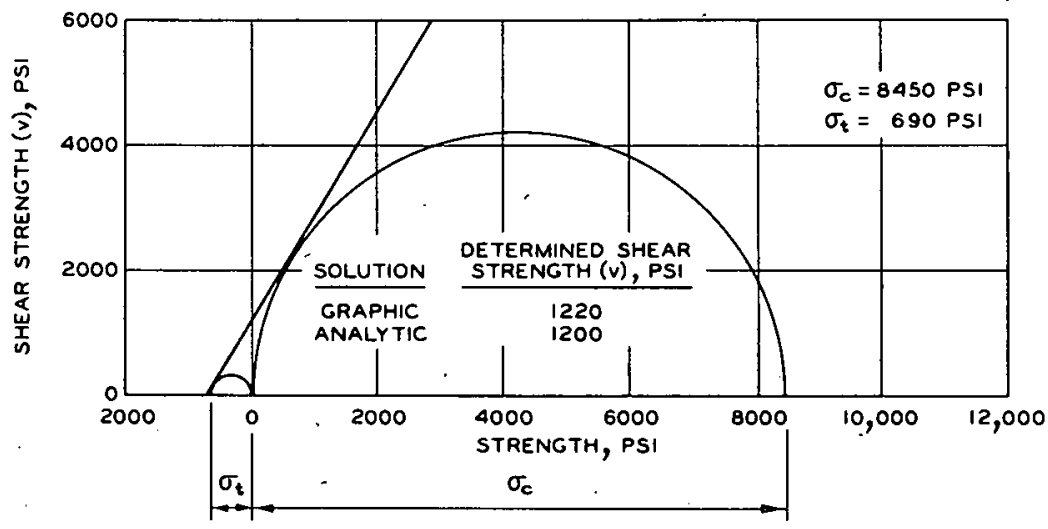

b. VESICULAR BASALT

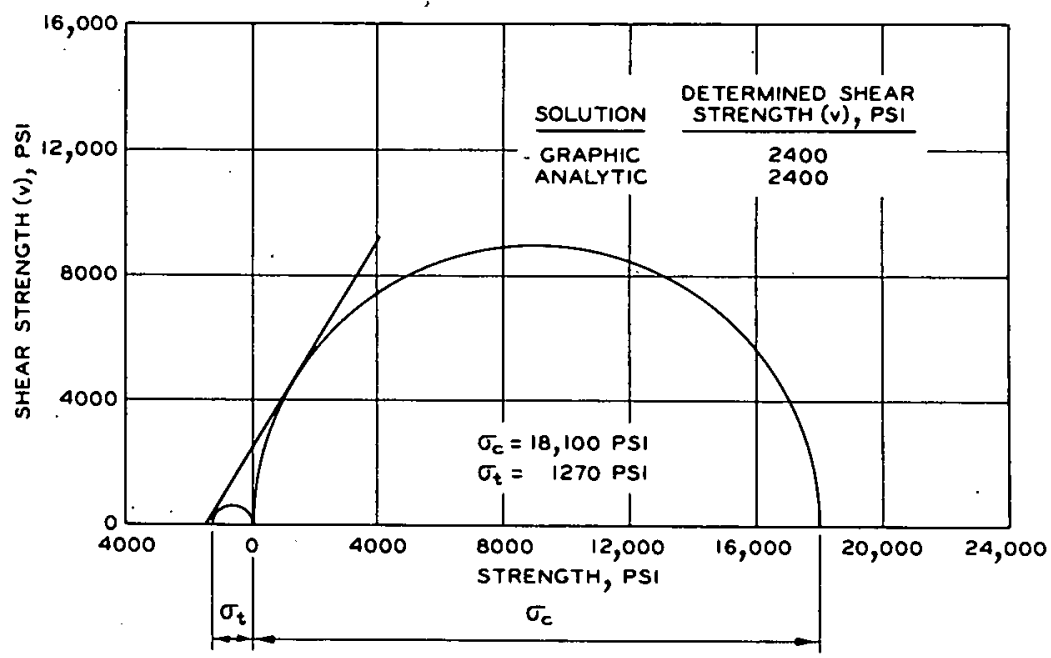

d. SOLID BASALT

Fig. B2. Graphic Mohr circle analysis for shear strength determination 

The following calculations show the effect of multiple rows of shear keys on their resistance efficiency.

$$
(x-0.7)(y-1.95)=1.125
$$

or

$$
y=\frac{1.125}{x-0.7}+1.95
$$

where

$$
\begin{aligned}
& x=\text { number of rows of keys } \geqq I \\
& y=\text { average shear strength of } x \text { rows of keys divided by } 500
\end{aligned}
$$

To change $y$. into efficiency, assume one row of keys gives $100 \%$ efficiency and substitute.

Let

$$
\begin{aligned}
& y=\text { efficiency, } E \\
& x=\text { number of rows of keys, } K \\
& \quad 100=\left(\frac{1.125}{1-0.7}+1.95\right) C_{c}
\end{aligned}
$$

where

$$
C_{c}=\text { constant coefficient }=17.56
$$

Therefore

$$
E=17.56\left(\frac{1.125}{K-0.7}+1.95\right)
$$

Example:

To compute the effect of a row of 7 keys:

$$
\begin{aligned}
E & =17.56\left(\frac{1.125}{7-0.7}+1.95\right) \\
& =17.56(2.13) \\
& =37.4
\end{aligned}
$$

or 7 rows will be $37.4 \%$ as effective on a load:area basis.

* Taken from work cited in footnote oń page 10 of text. 
A plot of MIT data on effect of shear keys is shown in fig. $\mathrm{Cl}$.

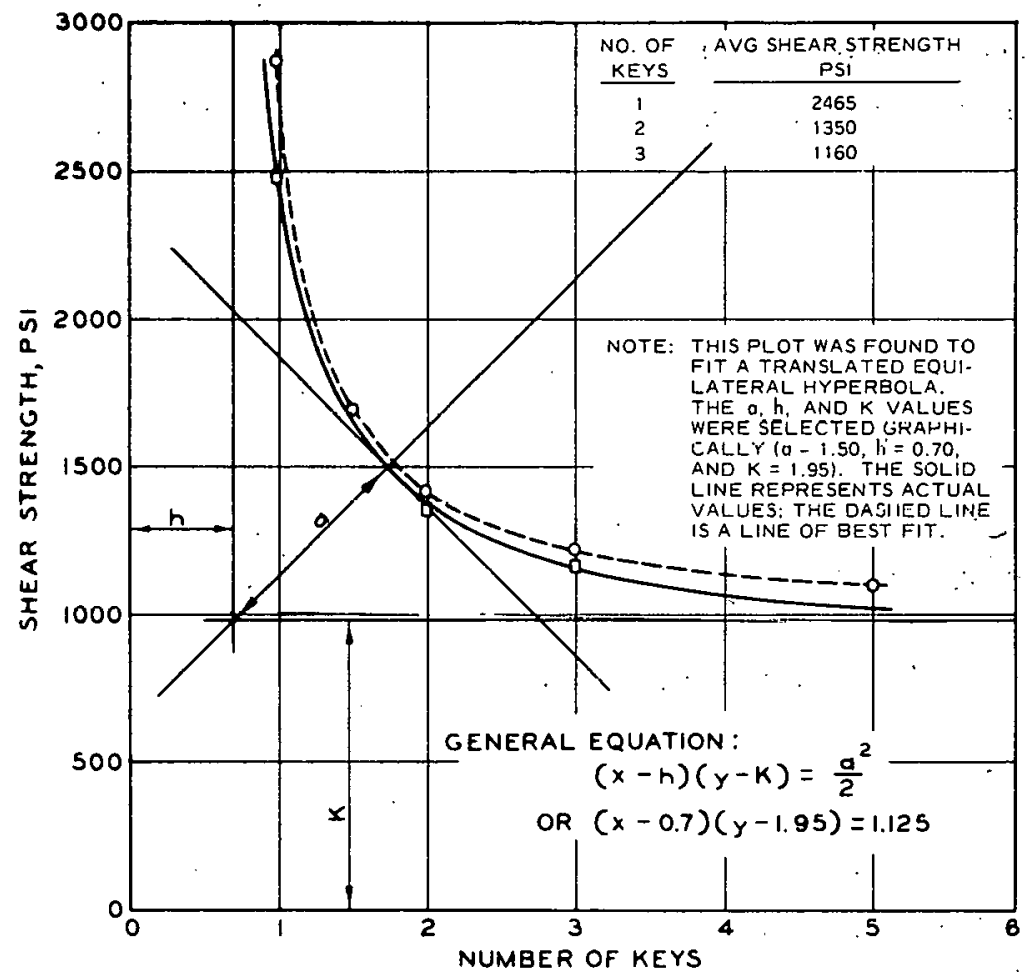

Fig. Cl. Plot of MIT data on effect of shear keys 
APPENDIX D: DESIGN CALCULATIONS 
GLOSSARY

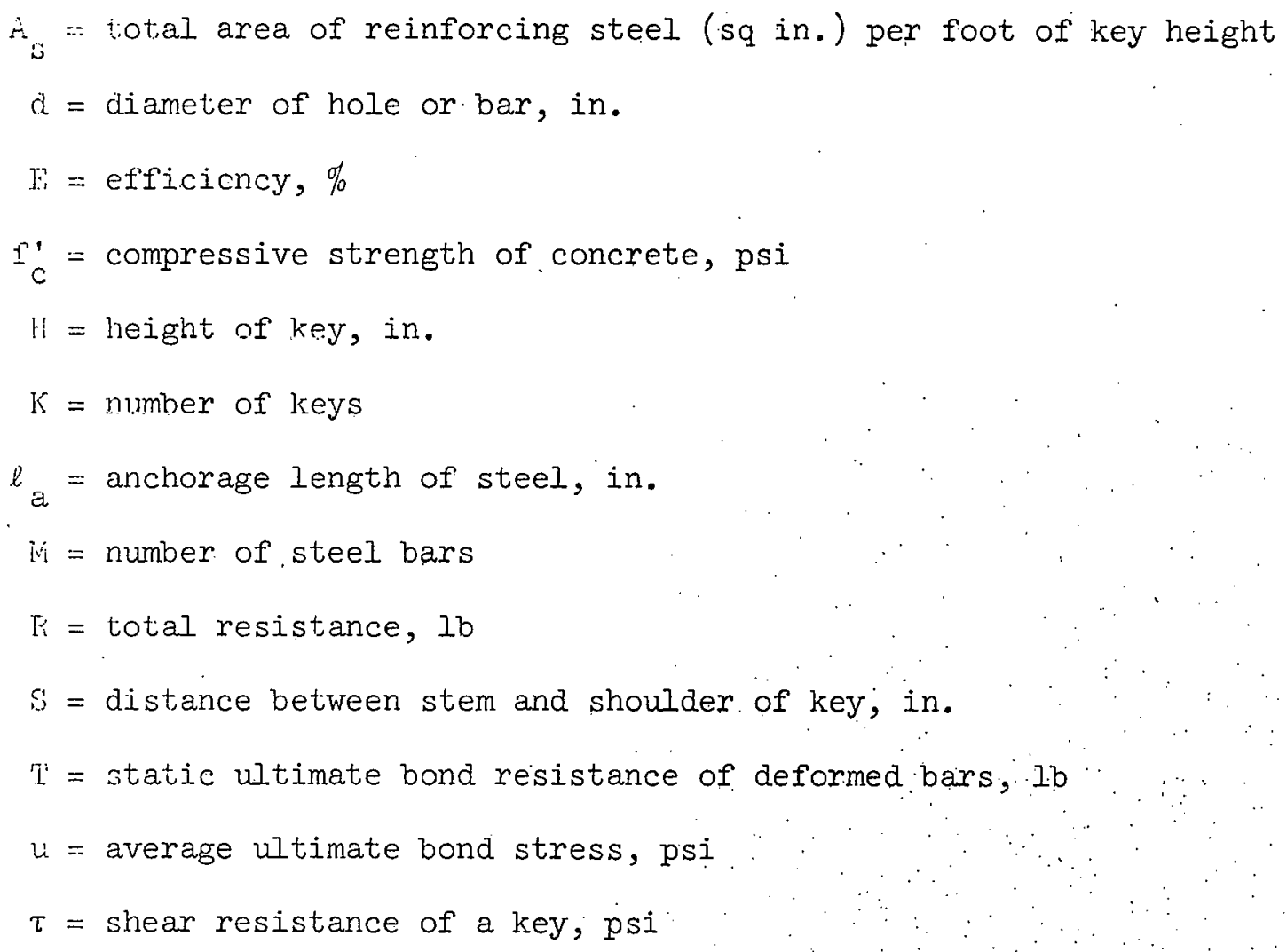




\section{APPENDIX D: DESIGN CALCULATIONS}

1. Holes 4.0 and 11.0. No keys required; however, include one 3-fthigh by 1.5-ft-deep key in each hole for safety. For convenience, tensile steel of size and amount used in other keys is to be used. Fï̈. DI shows the key details.

2. Hole 7.0 .

a. Shear resistance of solid basalt = hole circumference (in.) $\times$ shear strength (psi) $\times$ height of solid basalt region (in.)

$=113 \times 2400 \times 228=6.18 \times 10^{7} 1 \mathrm{~b}$

b. Available bond-shear resistance $=$ hole circumference (in.) $\times$ bond-shear (psi) $\times$ height of solid basalt region (in.)

$=113 \times 1180 \times 228=3.04 \times 10^{7} \mathrm{lb}$

c. Keys are needed to provide the additional $3.14 \times 10^{7} \mathrm{ib}$ shear resistance; try 2 keys.

a. Efficiency $(\mathrm{E})=17.56\left(\frac{1.125}{\mathrm{~K}-0.7}+1.95\right)$

For $K$ value of $2, E=49.5 \%$

e. Unit resistance $(\tau)$ of a key $=\ddot{E} \times 0.64 \times \dot{f}_{c}^{\prime}$

For $f_{c}^{\prime}$ of $5150(70 \%$ of 7360$)$ psi, $\tau=1630$ psi

f. Dimensions: Height $(\mathrm{H})$ of key $=\frac{R}{2 \pi d \tau}$.

$$
\mathrm{H}=\frac{3.14 \times 10^{7}}{2 \pi \mathrm{d} \tau}=85 \text { in. per key }
$$

Apply 20\% reduction for use of steel.

For mining convenience, use $\mathrm{H}=60$ in., $\mathrm{S}=24$ in.

g. Use sufficient reinforcement steel to match the tensile strength of the basalt. Dynamic tensile strengths of the solid basalt, concrete, and mild steel are 2480, 1260, and 63,600 psi, respectively.

Therefore

$(2480-1260) \pi \times 36 \times 12=1,655,0001 \mathrm{~b} /$ vertical foot

$$
\begin{aligned}
& A_{S}=\frac{1,655,000}{63,600} \\
& A_{s}=26.0 \mathrm{sq} \text { in. }
\end{aligned}
$$



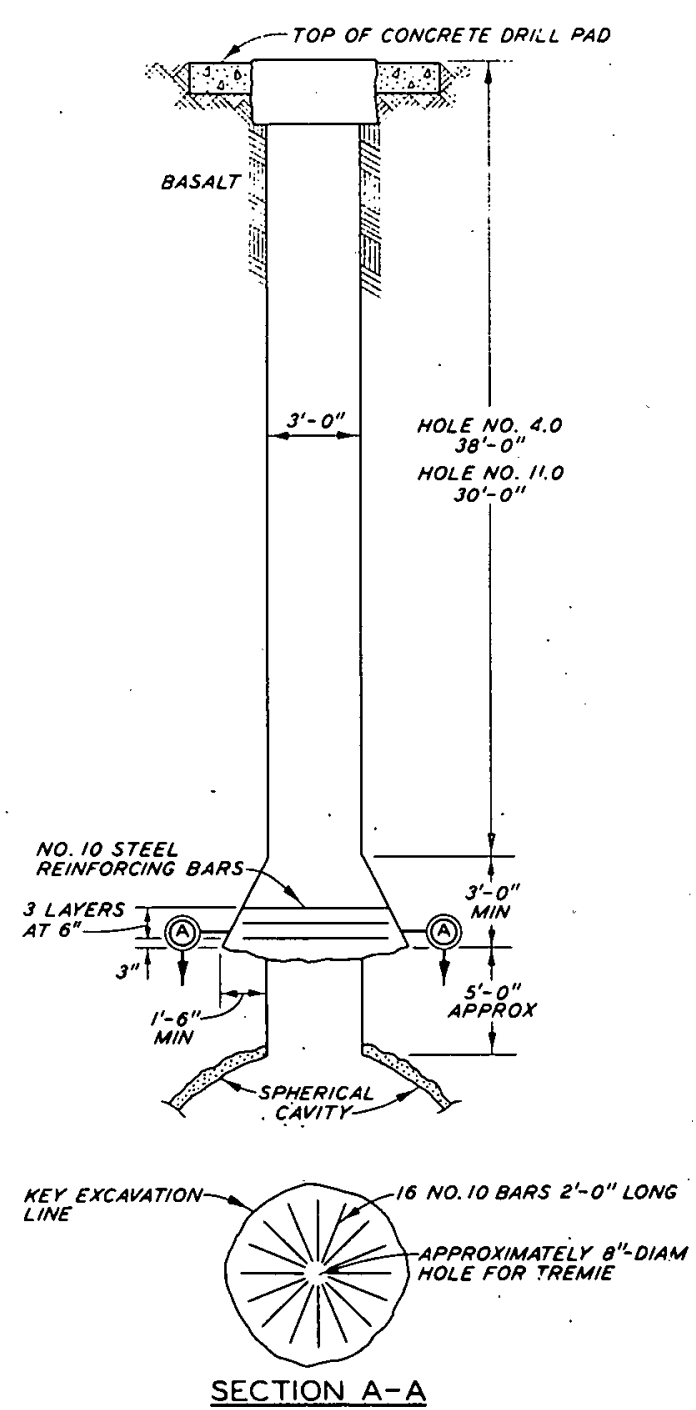

a. HOLES 4.0 AND 11.0

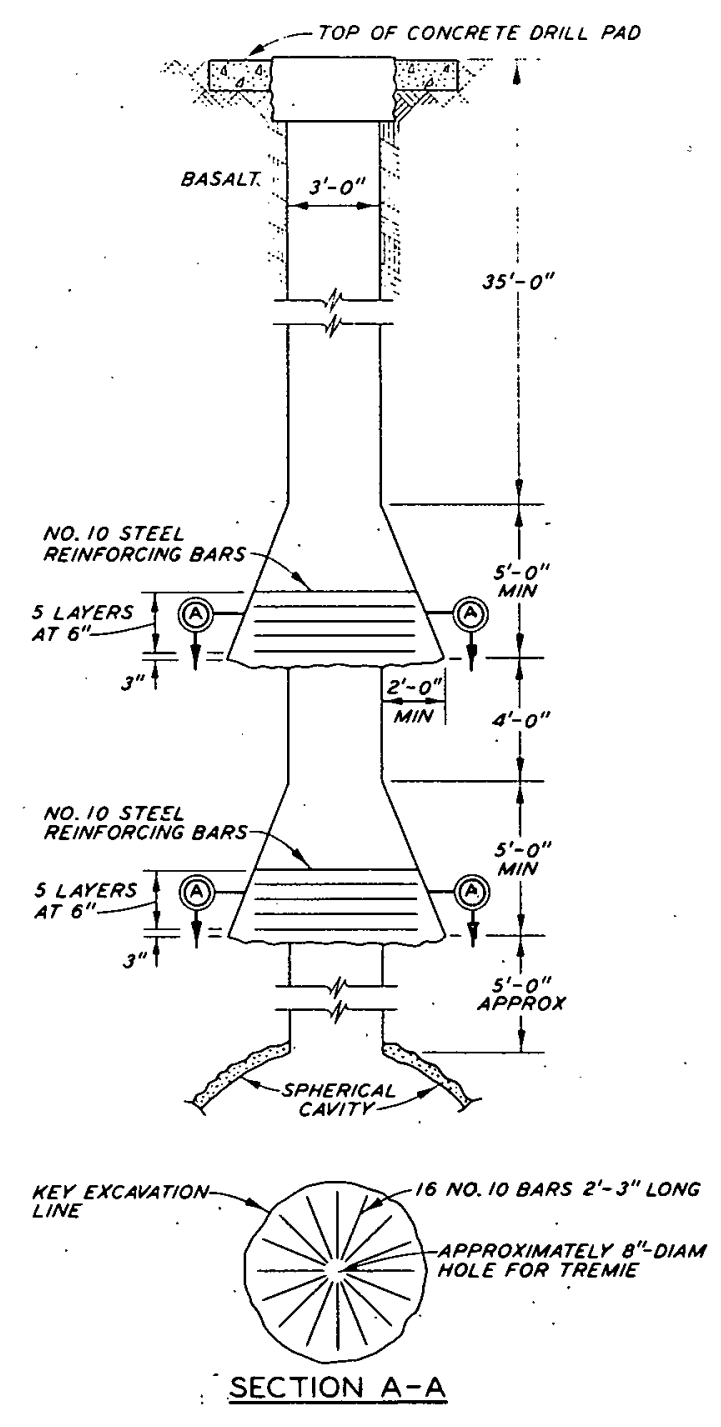

b. HOLE 7.0
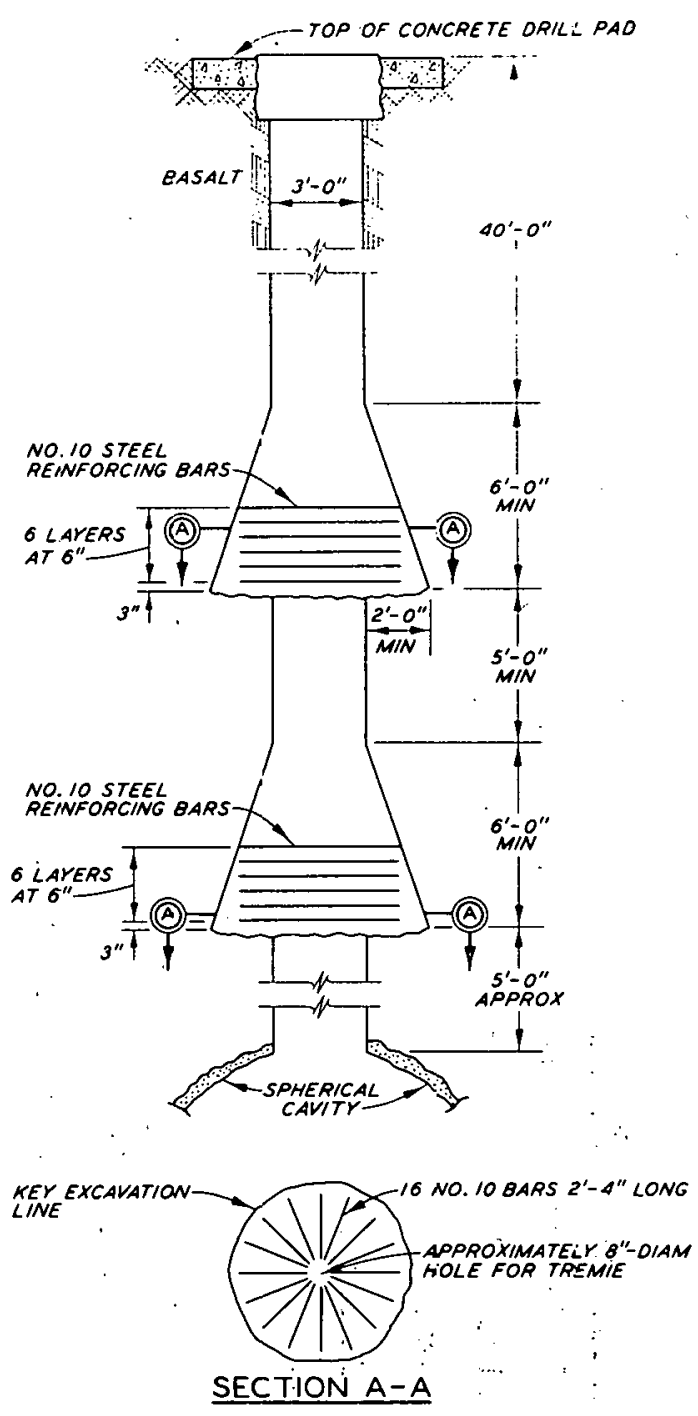

c. HOLE 3.0

Fig. Dl. Access holes 
Use No. 10 bars; diameter of each bar is 1.27 in.

No. of bars $/ f t=\frac{26.0}{1.27}=20.5$

Use 20 bars, or 10 extending through both sides

h. Check static ultimate tensịle resistance $(T)$.

$$
\begin{aligned}
& T=T_{S}(\text { steel })+T_{C} \text { (concrete) } \\
& \mathrm{T}_{\mathrm{S}}=\mathrm{urdl} \mathrm{a}^{\mathrm{M}} \\
& \mathrm{T}_{\mathrm{S}} \geqq 1,655,000.1 \mathrm{~b} \\
& M=\text { number of bar } s=20 \\
& \mathrm{~d}=\text { diameter of } \mathrm{bar}=1.27 \mathrm{in} . \\
& \ell_{a}=\text { anchorage length }=\text { maximum of } .12 \text { in } \text {. at midpoint } \\
& \mathrm{u}=\text { average ultimate bond stress }=500 \mathrm{psi} \\
& T_{S}=500 \times \pi \times 1.27 \times 12 \times 20 \\
& \mathrm{~T}_{\mathrm{S}}=478,560 \mathrm{lb} \\
& T_{C}=780 \times \pi \times 36 \times 12 \\
& \mathrm{~T}_{\mathrm{c}}=1,059,000 \mathrm{lb} \\
& T=T_{C}+T_{S}=1,537,5601 \mathrm{~b}
\end{aligned}
$$

This is adequate resistance considering that $u$ is probably conservative. Details of hole 7.0 are shown in fig. Dilb.

3. Hole 3.0.

a. Shear resistance of solid basalt. = hole circumference (in.) $x$ shear strength (psi) $\times$ height of solid basalt region (in.) $=113 \times 2400 \times 252=6.84 \times 10^{7} 1 \mathrm{~b}$

b. Available bond-shear resistance $=$ hole circumference (in.) $x$ bond-shear (psi) $\times$ height of solid basalt region (in.) $=113 \times 1180 \times 252=3.37 \times 10.7 \mathrm{~b}$

c. Keys are needed to provide the additional $3.47 \times 10^{7} \mathrm{lb}$ shear resistance; try 2 keys.

d. Efficiency $(E)^{-}=17.56\left(\frac{1.125}{\mathrm{~K}-0.7}+1.95\right)$ For $K$ value of $2, E=49.5 \%$. 
e. Unit resistance $(\tau)$ of a key. $=\mathrm{E} \times 0.64 \times \mathrm{f}_{\mathrm{c}}^{\prime}$

For $f_{c}^{\prime}$ of $5150(70 \%$ of 7360$)$ psi, $\tau=1630 \mathrm{psi}$

f. Dimensions: Height $(H)$ of key $=\frac{R}{2 \pi d \tau}$

$$
\mathrm{H}=\frac{3.47 \times 10^{7}}{2 \pi \mathrm{d} \tau}=94 \mathrm{in} \text {. per key }
$$

Apply 20\% reduction for use of steel.

For mining convenience, use $\mathrm{H}=72$ in., $\mathrm{S}=24 \mathrm{in}$.

g. Tensile strength reinforced in same manner as in hole 0.7, i.e. ten No. 10 bars per foot extending through both sides of key.

h. Check static ultimate tensile resistance ( $\mathrm{I}$ ').

$$
\begin{aligned}
& T=T_{S}(\text { steel })+T_{C} \text { (concrete) } \\
& \mathrm{T}_{\mathrm{S}}=\mathrm{u} \pi \mathrm{d} \ell_{\mathrm{a}}^{\mathrm{M}} \\
& \mathrm{T}_{\mathrm{S}} \geqq 1,655,000 \mathrm{Ib} \\
& M=\text { number of bars }=20 \\
& \mathrm{~d}=\text { diameter of } \mathrm{bar}=1.27 \mathrm{in} \text {. } \\
& \ell_{a}=\text { anchorage length }=\text { maximum of } 12 \text { in } . \text { at midpoint } \\
& u=\text { average ultimate bond stress }=500 \mathrm{psi} \\
& \mathrm{T}_{\mathrm{S}}=500 \times \pi \times 1.27 \times 12 \times 20 \\
& \mathrm{~T}_{\mathrm{S}}=478,5601 \mathrm{~b} \\
& T_{C}=780 \times \pi \times 36 \times 12 \\
& T_{c}=1,059,0001 \mathrm{~b} \\
& \mathrm{~T}=\mathrm{T}_{\mathrm{C}}+\mathrm{T}_{\mathrm{S}}=1,537,560 \mathrm{Ib}
\end{aligned}
$$

This is adequate resistance considering that $u$ is probably conservative. Details of hole 3.0 are shown in fig. Dlc. 


\section{DISTRIBUTION}

Basic Distribution:

TID-4500 (37th Ed.) UC-35, Nuclear Explosions -Peaceful Application

Supplementary Distribution:

U. S. Army Engineering Division, Lower Mississippi Valley

U. S. Army Engineer District, Memphis

U. S. Army Engineer District, New Orleans

U. S. Army Engineer District, St. Louis

U. S. Army Engineer District, Vicksburg

U. S. Army Engineering Division, Mediterranean

U. S. Army Liaison Detachment

U. S. Army Engineer District, Gulf (Teheran, Iran)

U. S. Army Engineering Division, Missouri River

U. S. Army Engineer District, Kansas City

U. S. Army Engineer District, Omaha

U. S. Army Engineering Division, New England

U. S. Army Engineering Division, North Atlantic

U. S. Army Engineer District, Baltimore

U. S. Army Engineer District, New York

U. S. Army Engineer District, Norfolk

U. S. Army Engineer District, Philadelphia.

U. S. Army Engineering Division, North Central

U. S. Army Engineer District, Buffalo

U. S. Army Engineer District, Chicago

U.S. Army Engineer District, Detroit

U. S. Army Engineer District, Rock Island

U..S. Army Engineer District, St. Paul

U. S. Army Engineer District, Lake Survey

U. S. Army Engineering Division, North Pacific.

U. S. Army Engineer District, Portlanā

U. S. Army Engineer District, Alaska

U. S. Army Engineer District, Seattle.

U. S. Army Engineer District, Walla Walla

U. S. Army Engineering Division, Ohio River

U. S. Army Engineer District, Huntington

U. S. Army Engineer District, Louisville

U. S. Army Engineer District, Nashvilie

U. S. Army Engineer District, Pittsburgh

U. S. Army Engineering Division, Pacific Ocean

U. S. Army Engineer District, Far East

U. 3. Army Englneer Iistrict, Honolulu

U. S. Army Engineer District, Okinawa

U. S. Army Engineering Division, South Atlantic 


\section{DISTRIBUTION (Continued)}

Supplementary Distribution (Continued):

U. S. Army Engineer District, Canaveral

U. S. Army Engineer District, Charleston

U. S. Army Engineer District, Jacksonville

U. S. Army Engineer District, Mobile

U. S. Army Engineer District, Savannah

U. S. Army Engineer District, Wilmington

U. S. Army Engineering Division, South Pacific

U. S. Army Engineer District, Tros Angeles

U. S. Army Engineer District, Sacramento

U. S. Army Engineer District, San Francisco

U. S. Army Engineering Division, Southwestern

U. S. Army Engineer District, Albuquerque

U. S. Army Engineer District, Fort Worth

U. S. Army Engineer District, Galveston

U. S. Army Engineer District, Little Rock

U. S. Army Engineer District, Tulsa

Beach Erosion Board, The

Mississippi River Commission

Rivers and Harbors, Boards of Engineers

Corps of Engineer Ballistic Missile Construction Office

U. S. Army Engineering Center and Ft. Belvoir

U. S. Army Engineer School

U. S. Army Engineering Reactors Group

U. S. A. Training Center, Engineer 
